\title{
Developing Schwann Cells Acquire the Ability to Survive without Axons by Establishing an Autocrine Circuit Involving Insulin-Like Growth Factor, Neurotrophin-3, and Platelet-Derived Growth Factor-BB
}

\author{
Carola Meier, Eric Parmantier, Angela Brennan, Rhona Mirsky, and Kristjan R. Jessen \\ Department of Anatomy and Developmental Biology, University College London, London, WC1E 6BT, United Kingdom
}

\begin{abstract}
Although Schwann cell precursors from early embryonic nerves die in the absence of axonal signals, Schwann cells in older nerves can survive in the absence of axons in the distal stump of transected nerves. This is crucially important, because successful axonal regrowth in a damaged nerve depends on interactions with living Schwann cells in the denervated distal stump. Here we show that Schwann cells acquire the ability to survive without axons by establishing an autocrine survival loop. This mechanism is absent in precursors. We show that
\end{abstract}

insulin-like growth factor, neurotrophin-3, and platelet-derived growth factor-BB are important components of this autocrine survival signal. The secretion of these factors by Schwann cells has significant implications for cellular communication in developing nerves, in view of their known ability to regulate survival and differentiation of other cells including neurons.

Key words: programmed cell death; apoptosis; nerve development; regeneration; Schwann cell precursors; autocrine loop; denervation
Survival regulation by signals that block or activate programmed cell death is important for the development and function of many systems, including the nervous system (Wyllie, 1980; Ellis and Youson, 1990; Oppenheim et al., 1991; Raff et al., 1993). We raised the issue of survival regulation during Schwann cell development by showing that Schwann cells from embryonic day 18 (E18) or newborn nerves survived for $24 \mathrm{hr}$ when plated without neurons at moderate cell density, although Schwann cell precursors from E14 nerves died by apoptosis under identical conditions (Jessen et al., 1994; Dong et al., 1995). We found that $\beta$-neuregulin-1 acted as a survival factor in this lineage, because $\beta$-neuregulin-1 prevented apoptosis of precursors and sustained their survival for several days, during which they converted to Schwann cells (Dong et al., 1995). These and related in vivo studies (Riethmacher et al., 1997) have now established that Schwann cell precursors depend on axons for survival, and that a major component of the axonal survival signal is $\beta$-neuregulin-1, which binds to ErbB3 receptors on the precursor cells (Jessen and Mirsky, 1997; for review, see Mirsky and Jessen, 1998).

More recently, it has become clear that Schwann cells also undergo programmed cell death. Apoptotic Schwann cells are present in nerves from newborn rats, and transection of neonatal nerves increases the amount of apoptosis, although this is not seen if 20-d-old nerves are cut (Grinspan et al., 1996; Syroid et al., 1996; Trachtenberg and Thompson, 1996). Even in neonatal

\footnotetext{
Received Aug. 6, 1998; revised Feb. 22, 1999; accepted Feb. 25, 1999.

This work was supported by the Wellcome Trust. C.M. and E.P. were recipients of Training and Mobility of Researchers fellowships from the European Commission. We are grateful to Dr. Y. Yarden for supplying ErbB4 protein, Dr. B. Ratzkin for supplying neuregulins, Regeneron Inc. for NT-3, NT-4, BDNF, and CNTF, and Drs. Y.-A. Barde, I. Bartke, P. H. Van der Meide, and T. M. Reilly for gifts of antibodies. We thank Dr. P. Topilko for help with diagrams and S. D. Bartram for expert typing and editing of this manuscript.

Correspondence should be addressed to Kristjan R. Jessen, Department of Anatomy and Developmental Biology, University College London, Gower Street, London, WC1E 6BT, UK.

Copyright (C) 1999 Society for Neuroscience $\quad 0270-6474 / 99 / 193847-13 \$ 05.00 / 0$
}

nerves it is clear that most Schwann cells survive nerve transection and the ensuing loss of axonal contact, and in adult nerves no significant Schwann cell death follows denervation (Trachtenberg and Thompson, 1996).

This raises the question of how Schwann cells survive in the absence of axons. This issue is critical in the context of nerve regeneration. In the nerve segment distal to an injury, Schwann cells are left without axons. For successful repair, the axons have to grow back through this segment to reach their targets. This axon regrowth is heavily dependent on the presence of living Schwann cells in the distal stump, presumably because the axons require interactions with Schwann cell-associated adhesion molecules and trophic factors (Hall, 1986; Fawcett and Keynes, 1990; Nadim et al., 1990). Nerve regeneration, therefore, depends on the mechanism that allows Schwann cells, unlike their precursors, to survive in the absence of axons.

We have now investigated the possibility that this is achieved by an autocrine loop, i.e., that Schwann cells might sustain their own survival by secretion of factors that block Schwann cell apoptosis. Using cell cultures we demonstrate the existence of autocrine survival loops in Schwann cells from E18 and postnatal nerves and find that these loops are absent from Schwann cell precursors. We provide evidence that the autocrine survival activity resides in a mixture of growth factors, including insulin-like growth factors (IGFs), platelet derived growth factor-BB (PDGF-BB), and neurotrophin-3 (NT-3), that acts synergistically to block Schwann cell death, although it does not prevent the death of Schwann cell precursors.

\section{MATERIALS AND METHODS}

All neutralizing monoclonal antibodies were used in the form of cell culture supernatant. A neutralizing monoclonal NT-3 antibody (mAb 12) was a gift from Dr. Y.-A. Barde (MPI, Martinsried, Germany) and Dr. I. Bartke (Boehringer Mannheim, Mannheim, Germany) (Gaese et al., 1994), and another polyclonal NT-3-neutralizing antibody, G1651, was obtained from Promega (Southampton, UK). The supernatant of the 
SM1.2 hybridoma cell line containing IGF-neutralizing antibodies, developed by Drs. J. J. Van Wyk and L. E. Underwood, was obtained from the Developmental Studies Hybridoma Bank maintained by the University of Iowa (Iowa City, IA) under contract NO-I-HD-7-3263 from the National Institute of Child Health and Human Development. This antibody binds both IGF-1 and -2. Neutralizing polyclonal IGF-2 antibody AF-292 was obtained from R \& D Systems (Oxon, UK). The AF-292 antibody does not neutralize IGF-1 according to the manufacturer's instructions. Blocking anti-IGF receptor I monoclonal antibodies (GR11L) were from Calbiochem-Novabiochem (Nottingham, UK). Neutralizing polyclonal PDGF-BB antibodies were from New Brunswick Scientific (Huntingdon, UK). Monoclonal DG2 antibodies neutralizing fibroblast growth factor-2 (FGF-2) were a gift from Dr. T. M. Reilly (DuPont Merck Pharmaceutical, Wilmington, DE) (Reilly et al., 1989). Neutralizing DB1 mouse anti-rat antibodies against interferon- $\gamma$ $(\mathrm{IFN}-\gamma)$ were a gift from P. H. Van der Meide. Polyclonal anti-brainderived neurotrophic factor (BDNF) neutralizing antibodies were obtained from Promega (Southampton, UK), and panspecific transforming growth factor $\beta$ (TGF- $\beta$ ) neutralizing antibodies were from $\mathrm{R} \& \mathrm{D}$ Systems.

IGF-1 and IGF-2 proteins were a gift from Kabi Pharmacia (Milton Keynes, UK). PDGF-BB and FGF-2 proteins were obtained from Peprotech (London, UK). NT-3, NT-4, and BDNF recombinant proteins were a gift from Regeneron Pharmaceuticals (Tarrytown, NY). Neuregulins were a gift from Dr. B. Ratzkin, (Amgen, Thousand Oaks, CA). Sensory and motor neuron-derived factor was a gift from Genentech (San Francisco, CA). Recombinant TGF- $\beta$ isoforms and leukemia-inhibitory factor (LIF) protein were obtained from R \& D Systems; endothelins 1 and 3 were from Cambridge Research Chemicals (Cheshire, UK). Recombinant glial-derived neurotrophic factor was obtained from Alomone Labs (Jerusalem, Israel), and nerve growth factor $2.5 \mathrm{~S}$ was from Promega (Southampton, UK). Tissue culture plastics were obtained from Falcon (Becton Dickinson, Cowley, UK) and Corning Costar (High Wycombe, UK), and culture media were from Life Technologies (Paisley, UK). Hyaluronidase, trypsin inhibitor, leupeptin, dimethylsulfoxide (DMSO), and tissue culture substrates were from Sigma (Poole, UK); collagenase was from Worthington (Lorne Laboratories, Reading, UK). Terminal transferase enzyme and buffer as well as biotin-16-dUTP nucleotides were obtained from Boehringer Mannheim (Lewes, UK); the fluoresceinated avidin conjugate was from Vector Laboratories (Burlingame, CA). RT-PCR reagents were obtained from Promega. Reverse transcriptase and primer pairs were from Life Technologies. Ultraspec RNA total RNA isolation reagent was from Biotecx Laboratories (Houston, TX).

Sources of other materials used in cell culture, immunocytochemistry, and RT-PCR have been detailed in previous papers (Jessen et al., 1994; Morgan et al., 1994; Dong et al., 1995; Blanchard et al., 1996).

Preparation of Schwann cell precursor and Schwann cell cultures. Throughout this study, Sprague Dawley rats were used. Cultures of Schwann cell precursors and Schwann cells from E18, newborn, and 7-d-old rats were prepared essentially as described previously (Jessen et al., 1990, 1994). After dissociation, Schwann cell precursors or embryonic Schwann cells were resuspended in defined medium without serum, counted, and plated at varying densities in a $20 \mu \mathrm{l}$ drop onto poly-Lornithine (PORN)-coated or poly-L-lysine- and laminin-coated coverslips. After $3 \mathrm{hr}$, the cultures were topped up with $380 \mu \mathrm{l}$ of different experimental media. The whole procedure was serum-free. Immunopanning was used to purify newborn Schwann cells (see below) before plating onto coverslips.

Purification of newborn Schwann cells by immunopanning. Negative immunopanning of Schwann cells was performed as described previously (Dong et al., 1997; Lee et al., 1997). Schwann cells are $99.5 \pm 0.4 \%$ pure after immunopanning as assessed by S100 staining (see below). For the preparation of Schwann cell conditioned medium, $2.5 \times 10^{6}$ cells were plated onto a 35-mm-diameter poly-L-lysine- and laminin-coated dish in $1.2 \mathrm{ml}$ of defined medium. To prevent protein degradation, cells were cultured in the presence of $20 \mu \mathrm{M}$ leupeptin. After a culture period of 24 hr the supernatant (conditioned medium) was collected, centrifuged for $10 \mathrm{~min}$ at $1000 \mathrm{rpm}$, and stored in BSA-coated cryotubes at $-70^{\circ} \mathrm{C}$ or used immediately. Before use, the conditioned medium was diluted in leupeptin-containing culture medium.

Defined medium. In most Schwann cell experiments a simple medium consisting of 1:1 DMEM and Ham's F-12 supplemented with bovine serum albumin $(350 \mu \mathrm{g} / \mathrm{ml})$ was used (referred to as simple defined medium or defined medium). In most precursor and some Schwann cell experiments we used a supplemented defined medium, identical to that used in previous studies (referred to as supplemented defined medium; Jessen et al., 1994). It consists of a 1:1 mixture of DMEM and Ham's F-12 supplemented with (final concentration in parentheses) transferrin $(100 \mu \mathrm{g} / \mathrm{ml})$, progesterone $(60 \mathrm{ng} / \mathrm{ml})$, putrescine $(16 \mu \mathrm{g} / \mathrm{ml})$, insulin $(5$ $\mu \mathrm{g} / \mathrm{ml})$, thyroxine $(0.4 \mu \mathrm{g} / \mathrm{ml})$, selenium $(160 \mathrm{ng} / \mathrm{ml})$, triiodothyronine $(10.1 \mathrm{ng} / \mathrm{ml})$, dexamethasone $(38 \mathrm{ng} / \mathrm{ml})$, glucose $(7.9 \mathrm{mg} / \mathrm{ml})$, bovine serum albumin $(0.3 \mathrm{mg} / \mathrm{ml})$, penicillin $(100 \mathrm{IU} / \mathrm{ml})$, streptomycin $(100$ $\mathrm{IU} / \mathrm{ml})$, and glutamine (2 mM).

Survival assay. The survival assay used in these experiments is a modification of that used previously for Schwann cell precursors (Jessen et al., 1994; Dong et al., 1995). Briefly, at $3 \mathrm{hr}$ and at specified times after plating, cells were fixed with $2 \%$ paraformaldehyde in PBS for $20 \mathrm{~min}$. After washing, cells were mounted in Citifluor mounting medium containing $4 \mu \mathrm{g} / \mathrm{ml}$ Hoechst dye. The number of living cells in this assay is expressed either as survival percent or rescue percent. Survival percent is the number of living cells present at the end of the experiment expressed as a percentage of the number of cells that had plated successfully at the beginning of the experiment, i.e., the number of cells that had attached and begun to flatten on the substrate $3 \mathrm{hr}$ after plating. Rescue percent is obtained by subtracting the number of cells in control sister cultures (i.e., the cells that survive without added survival factors) from the number of cells in a test culture (i.e., in the presence of added factors). This represents the number of cells rescued by the added factors. It is expressed as a percentage of the theoretical maximum rescue, which is the difference between the number of cells in control cultures (without added factors) and the number of cells that plated successfully at the beginning of the experiment (see above). Routinely, dead cells were identified by observing Hoechst nuclear staining and obvious morphological changes associated with death. Thus cells classified as dead showed either clearly elevated intensity of Hoechst nuclear labeling or nuclei that had fragmented, showing two or more Hoechstlabeled bodies per cell, and had in addition retracted processes and cytoplasm that by phase contrast appeared granulated and most often also vacuolated; the nucleus of these cells appeared condensed and/or fragmented by phase contrast. To validate the classification of these cells as dead, we examined cultures of dying cells that had been labeled with the terminal deoxynucleotidyl transferase-mediated dUTP-biotin nick end-labeling (TUNEL) method and classified the cells using these criteria. It was found that $98 \%$ of the cells that were recorded as dead using the above criteria were also TUNEL-positive. We used $13 \mathrm{~mm}$ coverslips, and in every case the total number of cells on the whole coverslip was counted.

Antibody blocking experiments and immunohistochemistry. Antibody concentrations for the neutralization of conditioned medium were determined for every antibody individually; neutralizing concentrations for the SM1.2 (IGF) and DG2 (FGF-2) antibodies were determined in Schwann cell proliferation assays (Stewart et al., 1991). Treatment with FGF-2, IGF-1, and forskolin resulted in $>80 \%$ bromodeoxyuridine (BrdU)-positive cells, which was reduced to control levels in the presence of $2.64 \mu \mathrm{g} / \mathrm{ml} \mathrm{SM} 1.2$ or $1 \mu \mathrm{g} / \mathrm{ml}$ DG2 antibodies, respectively. AntiPDGF-BB antibodies were also tested in a BrdU incorporation assay; concentrations of $12 \mu \mathrm{g} / \mathrm{ml}$ fully blocked BrdU incorporation in PDGFBB, IGF, and forskolin. For the IGF-2 antibody, the optimal concentration was determined by the reduction in survival rates of neonatal

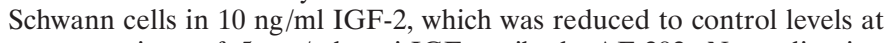
concentrations of $5 \mu \mathrm{g} / \mathrm{ml}$ anti-IGF antibody AF-292. Neutralization with the anti-NT-3 antibody mAb 12 has been described previously (Gaese et al., 1994); the concentration used was $50 \mu \mathrm{g} / \mathrm{ml}$. Concentrations for the NT-3 antibody G1651 were determined by blocking of NT-3-mediated Schwann cell survival (used at $2.5 \mu \mathrm{g} / \mathrm{ml}$ ). DB1 antiIFN- $\gamma$ antibodies were used as in previous experiments (1:50) in which they were used for neutralizing engodenous IFN- $\gamma$ in Schwann cell cocultures with lymphocytes (Kingston et al., 1989). For all antibodies, unspecific effects on Schwann cell survival were excluded by applying the antibodies to defined medium only and neuregulin-treated cultures: none of the antibodies reduced the survival of Schwann cells under these conditions. The specificities of all antibodies have been published previously (manufacturer's data and references).

Antibodies for immunohistochemistry were as follows. IGF-2 antibodies were from Autogen Bioclear/Cymbus Bioscience. This antibody shows $<0.01 \%$ cross-reactivity with IGF- 2 or insulin, respectively, according to the manufacturer's instructions. PDGF- $\beta$ receptor and TrkC antibodies were from Santa Cruz Biotechnology (Santa Cruz, CA), and IGF receptor type I (IGF-RI), PDGF-BB, and NT-3 (G1651) were the 
same as used in blocking experiments. For NT-3 immunolabeling cells were fixed in cold methanol; for IGF-2 immunolabeling cells were frozen twice, but not fixed, before the application of the primary antibody; for other antigens cells were fixed with $4 \%$ paraformaldehyde. In all cases, cells were preincubated in PBS, $0.1 \%$ Triton X-100, and $10 \%$ FCS, and the antibodies were diluted in the same solution. Omission of the first antibody served as a control. Photographs were taken using conventional and confocal fluorescence microscopes.

Mitogen-activated protein kinase inhibition assay. Three hours after plating, Schwann cells were preincubated in $360 \mu \mathrm{l}$ of defined medium containing the mitogen-activated protein kinase kinase 1/2 (MEK 1/2) inhibitor PD98059 (New England Biolabs, Hitchin, UK) for $1 \mathrm{hr}$. Without changing the medium, $40 \mu \mathrm{l}$ of $10 \times$ concentrated solutions of the appropriate growth factors or conditioned medium was applied to the wells. The stock dilution of PD98059 was prepared at a concentration of $2.5 \mu \mathrm{M}$ in DMSO, final concentrations were 20,35 , and $50 \mu \mathrm{M}$.

$D N A$ synthesis assay. This assay was performed, as described previously (Stewart et al., 1991; Jessen et al., 1994; Dong et al., 1995). Swiss 3T3 cells (a gift from Dr. R. Treisman) were cultured in $0.5 \%$ fetal calf serum on noncoated glass coverslips. After $10 \mathrm{~d}$ in vitro the cells were switched to different experimental media. Twenty-four hours later, BrdU was added to the culture medium, and another $20 \mathrm{hr}$ later the cells were fixed and immunolabeled.

Terminal transferase assay for cell death detection. Cell death was also assessed using a detection method based on the TUNEL assay described by Gavrieli et al. (1992). After fixation of cells in 4\% paraformaldehyde, cells were washed in Tris-buffered saline and immersed in terminal desoxynucleotidyl transferase buffer. The tailing reaction was performed in $25 \mathrm{~mm}$ Tris- $\mathrm{HCl}, \mathrm{pH}$ 6.6, $200 \mathrm{~mm}$ potassium cacodylate, $1 \mathrm{~mm}$ cobalt chloride, $0.25 \mathrm{mg} / \mathrm{ml}$ bovine serum albumin, $2.5 \mu \mathrm{M}$ biotin-16-dUTPs, 10 $\mu \mathrm{M}$ dATP, and $0.125 \mathrm{U} / \mu \mathrm{l}$ terminal transferase in a humidified container at $37^{\circ} \mathrm{C}$ and $5 \% \mathrm{CO}_{2}$ for $1 \mathrm{hr}$ and terminated by transferring to $2 \times \mathrm{SSC}$. After blocking in 4\% BSA and 5\% nonfat dry milk in PBS, TUNELpositive cells were visualized with fluoresceinated avidin.

$R N A$ preparation. Ultraspec RNA total RNA isolation reagent was used, according to the manufacturer's instructions, to purify RNA. Total RNA was extracted from sciatic nerve and brachial plexus freshly dissected from E14, E16, E18, and newborn rats. In other experiments, total RNA was made from immunopanned Schwann cells prepared from newborn rats and plated in tissue culture plastic dishes as described above. For transection of the sciatic nerve, 4-d-old rats were anesthetized with halothane, and the right sciatic nerve was transected. The proximal end of the axotomized nerve was reflected to prevent nerve regeneration. Two and $4 \mathrm{~d}$ after axotomy both the distal end of the transected nerve and contralateral intact nerve were dissected and immediately used for total RNA preparation.

Semiquantitative RT-PCR. In most cases, $500 \mathrm{ng}$ of total RNA was reverse-transcribed into cDNA in a $50 \mu \mathrm{l}$ reaction containing $50 \mathrm{~mm}$ Tris-HCl, pH 8.3, 75 mm KCl, 3 mm $\mathrm{MgCl}_{2}$, 10 mm DTT, 0.5 mm dNTPs, $100 \mathrm{ng}$ of random hexamers as primer, and $200 \mathrm{U}$ of $\mathrm{RNase} \mathrm{H}^{-}$reverse transcriptase (Superscript II). For detection of IGF-1 and IGF-RI in the neonatal sciatic nerve and cultured Schwann cells, the RNA amount for the cDNA synthesis was 10 times higher in the case of IGF-1 detection and 50 times higher for IGF-RI detection. The reaction was incubated for $90 \mathrm{~min}$ at $42^{\circ} \mathrm{C}$, followed by $10 \mathrm{~min}$ at $70^{\circ} \mathrm{C}$. RNA was removed by incubating the reaction for $30 \mathrm{~min}$ at $37^{\circ} \mathrm{C}$ in the presence of RNase $\mathrm{A}(0.2$ $\mathrm{mg} / \mathrm{ml})$. The relative amount of cDNA synthesized from each sample was determined by RT-PCR amplification using 18S rRNA-specific primers (Owens and Boyd, 1991). The primer pairs were designed as follows (product size in parentheses): NT-3, forward primer, 5'-GGTTGCAGGGGGATTGAT-3'; reverse primer, 5'-TATTCGTATCCAGCGCCA-3' (116 bp); TrkC, forward primer, 5'-GCCAAGGGGGAGCTAGGACT-3'; reverse primer, 5'-AGCTCCACACATCACTCTCT-3' (341 and 299 bp; Offenhäuser et al., 1995); IGF-1, forward primer, 5'GGACCAGAGACCCTTTGCGGGG-3'; reverse primer, 5'-GGCTGCTTTTGTAGGCTTCAGTGG-3' (210 bp; Bell et al., 1986); IGF-RI, forward primer, 5'-GCAAGTTCTTCGTTTCGTCATGG-3'; reverse primer, 5'-TTGTTCTCCTCGCTGTAGTAGAGG-3' (200 bp); IGF-2, forward primer, 5'-GTTCTTCAAATTCGACACCTGGAG-3'; reverse primer, 5'-TGATGGTTGCTGGACATCTCCG-3' (203 bp); IGF-RII, forward primer, 5'-TGTACACTCTTCTTCTCCTGGCA-3'; reverse primer, 5'-AGAGATGTTGATGTAGAAGACAGG-3' (186 bp; Rappolee et al., 1992); PDGF-B, forward primer, 5'-AGACGAAGATGGGGCTGAGCTG-3'; reverse primer, 5'-CACTGCACATTGCGGTTATTGC-3' (263 bp); and PDGF-R $\beta$, forward primer, 5'-GTTCGT-
CCTCAACATTTCGAGC-3'; reverse primer, 5'-AAACCTCGCTGGTGGTCATAGG-3' (413 bp).

One microliter of cDNA, corresponding to $10 \mathrm{ng}$ of equivalent total RNA (100 and $500 \mathrm{ng}$ for IGF-1 and IGF-RI detection in postnatal day 0 nerve and cultured Schwann cells, respectively; see above), was amplified in $100 \mu \mathrm{l}$ of PCR reactions containing $1 \times$ reaction buffer $(10 \mathrm{~mm}$ Tris- $\mathrm{HCl}$, pH 9.0, $50 \mathrm{~mm} \mathrm{KCl}$, and $0.1 \%$ Triton X-100), $1.5 \mathrm{~mm} \mathrm{MgCl}_{2}$, $0.2 \mathrm{~mm}$ dATP, dGTP, dTTP, dCTP, 50 pmol of each primer (listed above; 25 pmol for the TrkC primer pair) and $1.5 \mathrm{U}$ of Taq DNA polymerase. $\mathrm{MgCl}_{2}$ concentration, annealing temperature, and cycle number were optimized for each primer pair.

After an initial step at $94^{\circ} \mathrm{C}$ for $3 \mathrm{~min}$, cycling conditions were $94^{\circ} \mathrm{C}$ for $30 \mathrm{sec}, 60^{\circ} \mathrm{C}$ for $1 \mathrm{~min}\left(55^{\circ} \mathrm{C}\right.$ for the NT-3 and TrkC primer pairs), and $72^{\circ} \mathrm{C}$ for $30 \mathrm{sec}$ before a final extension period of $5 \mathrm{~min}$ at $72^{\circ} \mathrm{C}$. To check that the product was accumulating in a linear manner, $1 / 10$ of each reaction was electrophoresed at three cycle intervals (at a stage at which product accumulation could be visualized) on a 2 or $2.5 \%$ agarose gel stained with ethidium bromide. Numbers of cycles (indicated in the figure legends) used in the RT-PCR reactions illustrated in Figure 6 were within the linear part of the amplification profile.

\section{RESULTS}

\section{Schwann cell death can be blocked by autocrine survival loops}

If Schwann cells secrete factors that regulate their own survival, survival should be low at low cell density in vitro. To test this, cells were dissociated from nerves of newborn animals, purified by immunopanning, and plated at densities ranging from 125 to 12,000 cells per coverslip in simple defined medium. Two days later the cells were fixed and treated with Hoechst dye, and the number of surviving cells was counted using phase contrast and fluorescence microscopy (Fig. 1A). Cell survival was densitydependent: $89 \%$ survival was obtained with 12,000 cells, whereas only $52 \%$ of the cells survived over the 2 d period when 125 cells were plated on PORN-coated coverslips. These cells died during the next few days in vitro, indicating that death in low-density cultures was not restricted to a subpopulation of cells (Fig. 1B). The death in sparse cultures was not blocked by cell-cell contact, because the survival was the same when 2000 cells were initially plated in $20 \mu \mathrm{l}$ drops, in which case most cells were seen to contact each other, or in $80 \mu \mathrm{l}$ drops, in which most cells were single (data not shown).

The DNA condensation seen by the Hoechst staining indicated death by apoptosis, and this was further supported by the use of the TUNEL technique (Fig. $1 D-G$ ).

If Schwann cells secrete soluble survival factors, Schwann cell conditioned medium should rescue Schwann cells that would otherwise die in sparse cultures. We tested this using a $2 \mathrm{~d}$ survival assay and found that simple defined medium conditioned for $1 \mathrm{~d}$ by dense cultures of immunopanned cells from nerves of 7-d-old rats blocked cell death in low-density cultures (Fig. 1C). The conditioned medium acted in a dose-dependent manner, with optimum survival seen at a 10 -fold dilution $(99 \pm 0.6 \%$ of the cells were rescued). To test whether the Schwann cell-derived survival-promoting activity stimulated DNA synthesis in Schwann cells, in addition to blocking apoptosis, the BrdU assay and immunohistochemistry were used to detect DNA synthesis during the last $20 \mathrm{hr}$ in high-density cultures containing 12,000 cells per coverslip maintained for $2 \mathrm{~d}$. Although these conditions supported 95-100\% survival, DNA synthesis was essentially absent $(<0.1 \%)$. In positive control experiments, exposure of similar cultures to the established Schwann cell mitogen combination of FGF-2, IGF-1, and the cAMP-elevating agent forskolin (Stewart et al., 1996) resulted in $>80 \%$ of the Schwann cells having BrdU-labeled nuclei (see below). Conditioned medium, applied 

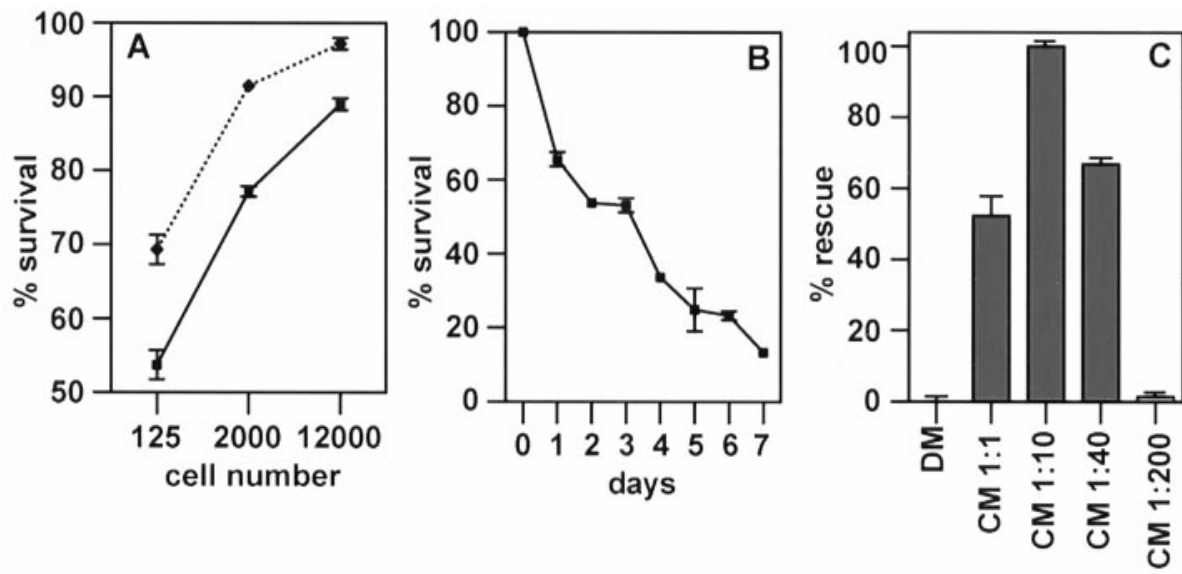
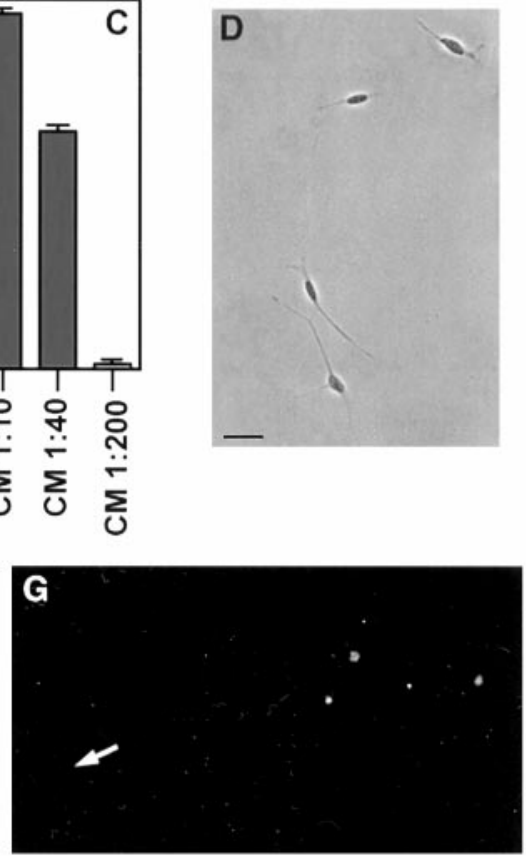
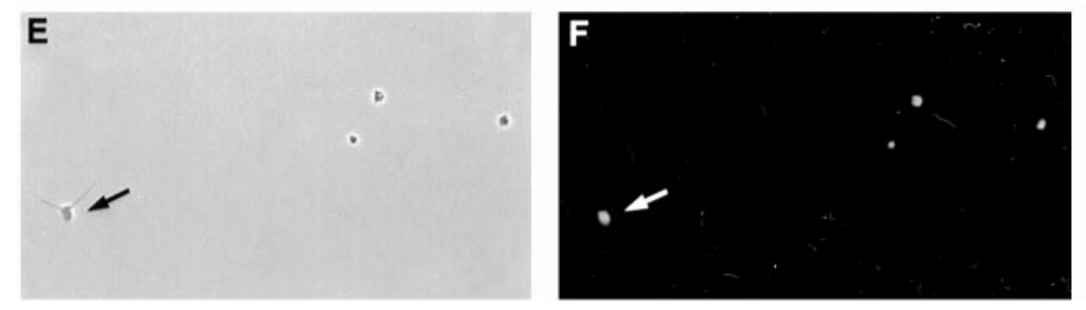

Figure 1. Autocrine survival circuit in Schwann cells. $A$, The survival of neonatal Schwann cells is density-dependent. Note that survival increases with higher cell number, indicating secretion of autocrine growth factors into the medium. PORN (heavy line) and laminin (dotted line) substrate, $2 \mathrm{~d}$ assay. $B$, Survival of low-density cultures decreases with time. PORN substrate, 125 cells per coverslip. $C$, Cells destined to die in low-density cultures can be rescued by Schwann cell conditioned medium. PORN substrate, 125 cells per coverslip, 2 d assay. DM, Simple defined medium; CM, Schwann cell conditioned medium; numbers indicate dilutions with simple defined medium. $D$, Appearance of Schwann cells in low-density cultures maintained in conditioned medium (1:10) for 2 d. Note elongated morphology. PORN substrate, phase contrast optics. $E-G$, Schwann cells in low-density cultures die by apoptosis in the absence of growth factors. E, Appearance of Schwann cells in low-density cultures maintained in simple defined medium for $2 \mathrm{~d}$. Note a high proportion of dead or dying cells and a living cell (arrow) with typically short processes. PORN substrate, phase contrast optics. $F$, Same field; Hoechst staining of Schwann cell nuclei shows DNA condensation in dead cells. G, Same field; TUNEL labeling of dead Schwann cells indicates DNA fragmentation. The living cell (arrow) is unlabeled. Scale bar $(D-G), 20 \mu \mathrm{m}$. In this and all subsequent graphs, each point represents the average of at least three independent experiments \pm SEM. For definition of percent survival and percent rescue see Materials and Methods.

to low-density cultures, also supported full survival without any proliferation (see below).

Taken together these experiments indicated (1) that Schwann cells can use autocrine growth factor loops to prevent their own apoptosis, and (2) that at concentrations sufficient to block death, the factor(s) involved do not stimulate Schwann cell DNA synthesis.

\section{Experiments with neutralizing antibodies indicate that IGF, NT-3, and PDGF-BB are components of the autocrine growth factor loop}

As a first step toward establishing the molecular identity of the autocrine Schwann cell survival activity, we tested whether the effects of Schwann cell conditioned medium could be mimicked by known growth factors. Using sparse cultures (125 cells per coverslip) and relatively high growth factor concentrations, we examined the ability of a number of growth factors to promote the survival of immunopanned Schwann cells over $4 \mathrm{~d}$. In these and all subsequent experiments unless otherwise stated, the cells were plated on PORN-coated glass coverslips. The factors included LIF, ciliary-derived neurotrophic factor, epidermal growth factor, endothelin-1 and -3, FGF-2, nerve growth factor, BDNF, NT-4, glial-derived neurotrophic factor, IGF-1, IGF-2, NT-3, PDGF-AA, and PDGF-BB. Only IGFs (30-100 ng/ml), NT-3 (30 $\mathrm{ng} / \mathrm{ml})$, and PDGF-BB (30 ng/ml) enhanced survival in these experiments significantly (20-30\% compared with defined medium controls).

This, together with the fact that all three factors have been implicated in aspects of Schwann cell development and differentiation (Eccleston et al., 1993; Cheng et al., 1996; Stewart et al., 1996; Verdi et al., 1996; Oudega et al., 1997) and can be expressed by Schwann cells (see below; for review, see Scherer and Salzer, 1996), raised the possibility that IGFs, NT-3, and PDGF-BB were produced and secreted by Schwann cells and collectively formed the autocrine survival loop.

To examine this, we tested whether blocking antibodies against IGF, NT-3, or PDGF-BB would interfere with the ability of conditioned medium to prevent cell death in sparse cultures (125 cells per coverslip) over $2 \mathrm{~d}$. We found that two different IGF antibodies completely abolished the ability of Schwann cell conditioned media to rescue Schwann cells (Fig. $2 A$ ). These antibodies were the SM1.2 antibody (Van Wyk et al., 1985), which blocks the biological activity of IGF-1 and -2, and another IGF antibody (AF-292), which primarily neutralizes IGF-2. In control experiments, we verified the ability of both of these antibodies to block specifically the effects of recombinant IGFs on Schwann cells (see Materials and Methods). An NT-3 antibody, mAb 12, which has previously been used to block the effects of endogenous NT-3 in many systems (Gaese et al., 1994; Brill et al., 1995), also strongly reduced the potential of conditioned media to rescue Schwann cells, and again, this effect was confirmed using an alternative neutralizing NT-3 antibody, G1651 (Fig. 2A). These antibodies reduced the rescue potential of the conditioned medium by $50-$ $80 \%$. Last, we found that a neutralizing PDGF-BB antibody reduced the ability of Schwann cell conditioned media to rescue 

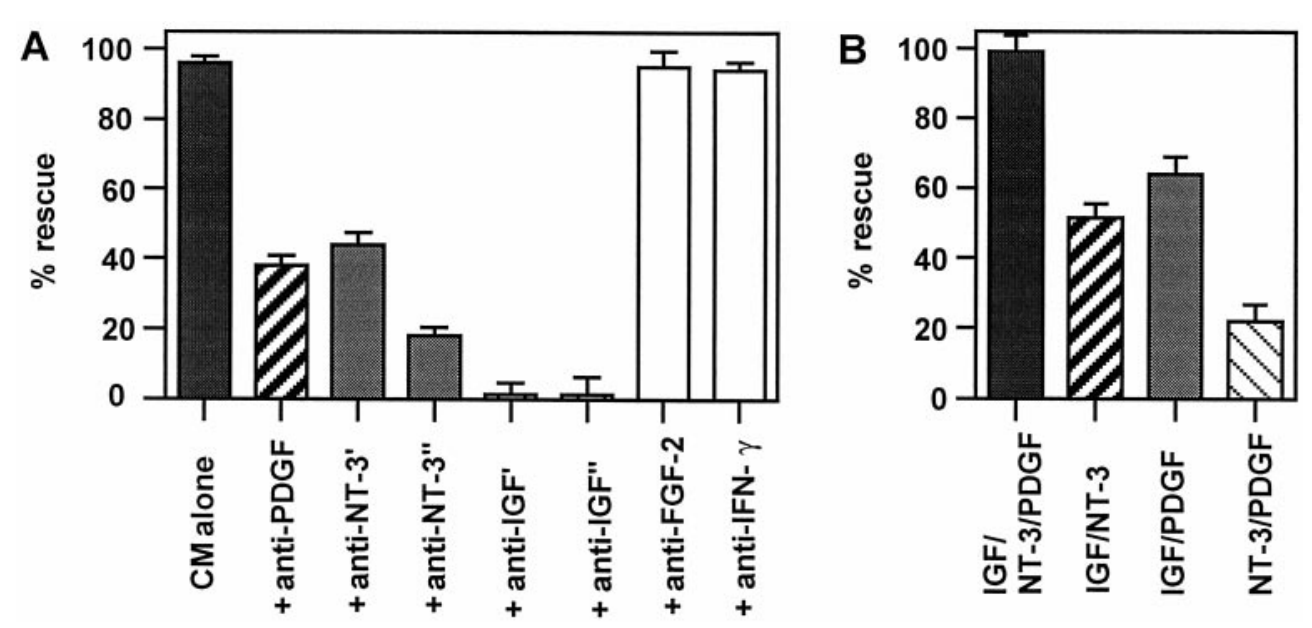

Figure 2. Similarities between the autocrine Schwann cell survival signal and IGF-2, NT-3, and PDGF-BB. $A$ Neutralizing antibodies to IGF, NT-3, and PDGF-BB inhibit the survival activity in Schwann cell conditioned medium. Both IGF antibodies completely abolish the ability of conditioned medium to rescue Schwann cells, whereas lesser but substantial inhibition is seen with the PDGF-BB and both NT-3 antibodies. Blocking antibodies to FGF-2 and IFN- $\gamma$ have no effect on survival. PORN substrate, $2 \mathrm{~d}$ assay, CM alone, Schwann cell conditioned medium diluted 1:10; anti-NT-3', NT-3 antibody $\mathrm{mAb} 12$; anti$N T-3^{\prime \prime}$, NT-3 antibody G1651; anti-IGF', IGF antibody SM1.2 (recognizes both IGF-1 and -2); anti-IGF", IGF-2 antibody AF-292. $B$, The combination IGF-2, NT-3, and PDGF-BB in a minimal mixture of $1.6,0.8$, and $0.8 \mathrm{ng} / \mathrm{ml}$, respectively, mimics the survival promoting effect of Schwann cell conditioned medium. Shading of columns relates to $A$. Note that the minimal mixture rescues all cells and that the order of potency of all four combinations shown in $B$ is the one predicted by the neutralizing experiments shown in $A$. PORN substrate, 125 cells per coverslip, $2 \mathrm{~d}$ assay.

Schwann cells by $60 \%$ (Fig. $2 A$ ). We confirmed that these antibodies specifically blocked the mitogenic effect of recombinant PDGF-BB on cultured Schwann cells (see Materials and Methods). Survival levels were not further reduced by combined application of anti-NT-3 and anti-PDGF antibodies (data not shown). In control experiments, blocking antibody DG2 against FGF-2, blocking antibody DB1 against IFN- $\gamma$ (Fig. $2 A$ ), and antibodies to TGF- $\beta$ and BDNF (data not shown) had no significant effects on survival. Furthermore, the IGF antibodies did not reduce Schwann cell survival induced by NT-3 and PDGF-BB, the NT-3 antibodies did not reduce survival induced by IGF and PDGF-BB, and the PDGF-BB antibodies did not reduce survival supported by IGF and NT-3 (for documentation of the survivalpromoting activity of these growth factor combinations, see below). None of these antibodies reduced the ability of $\beta$-neuregulin-1 to support Schwann cell survival (see below).

The idea that IGFs acting via IGF-RI were a component of the autocrine survival mechanism was further indicated by the observation that insulin at concentrations high enough to bind to IGF-RI could substitute for the activity neutralized by IGF antibodies. In this series of experiments, using 125-cell cultures and a 2 d survival assay, we found that a control survival of $49 \%$ in defined medium only was raised to $97 \%$ in the presence of conditioned medium, suppressed to $45 \%$ (i.e., control levels) by adding IGF antibodies to the conditioned medium, but raised again to $95 \%$ when insulin $(5 \mu \mathrm{g} / \mathrm{ml})$ was added to the mixture of conditioned medium plus IGF antibodies. Neutralizing antibodies to IGF-RI were tested in two experiments and found to reduce the rescue potential of Schwann cell conditioned media by $50-$ $55 \%$. Using different methods we have previously reported that PDGF-BB can act as an autocrine mitogen in Schwann cells (Eccleston et al., 1990, 1993).

Together, these experiments indicate that the survivalpromoting activity found in media conditioned by Schwann cells can be accounted for by a combination of growth factors, including IGFs, NT-3, and PDGF-BB. The reported affinities of the two IGF antibodies for IGF-1 and -2, respectively (see Materials and Methods), suggest that IGF-2 is the major IGF component (also see immunohistochemical experiments using IGF-2 antibodies below).

\section{A mixture of IGF, NT-3, and PDGF-BB mimics the effects of Schwann cell conditioned medium}

The experiments with blocking antibodies indicated that the survival activity in Schwann cell conditioned media can largely be accounted for by a combination of IGFs, NT-3, and PDGF-BB. It can be assumed that the conditioned medium is a complex combination of a number of factors in addition to these three. Nevertheless, if IGF, NT-3, and PDGF-BB together constitute a critical survival signal, it should be possible to come close to mimicking the survival activity of the medium by using a mixture of the three factors only. The antibody experiments gave rise to certain specific predictions for such experiments: (1) a combination of IGF, NT-3, and PDGF-BB should completely rescue Schwann cells in an assay similar to that used to test the conditioned medium; (2) the concentrations of the factors should be such that all three factors are required for full survival; and (3) at these concentrations, the combination of IGF with either NT-3 or PDGF-BB should clearly be more effective than the combination of NT-3 with PDGF-BB.

By performing survival assays using recombinant growth factors at various concentrations, we identified combinations of IGF, NT-3, and PDGF-BB that fulfilled these criteria. The lowest concentrations that mimicked Schwann cell conditioned medium were IGF-1 and IGF-2 at 1-2 ng/ml together with NT-3 and PDGF-BB at $0.5-1 \mathrm{ng} / \mathrm{ml}$. Routinely, we therefore adopted the combination of IGF-2 (1.6 ng/ml, $0.2 \mathrm{nM}), \mathrm{NT}-3(0.8 \mathrm{ng} / \mathrm{ml}, 0.055$ $\mathrm{nM})$, and PDGF-BB $(0.8 \mathrm{ng} / \mathrm{ml}, 0.03 \mathrm{~nm})$ as the most parsimonious way of mimicking the effects of Schwann cell-derived factors on Schwann cell survival (Fig. 2B). Neither NT-3 nor PDGF-BB had significant effects on their own at these concentrations (see below and Fig. 3), and survival activity only increased modestly when they were applied together. The combinations of IGF-2 plus NT-3 or IGF-2 plus PDGF-BB achieved 50-60\% rescue. At these concentrations, therefore, complete rescue of Schwann cells depended on the presence of all three components.

To further analyze the survival effects of IGF-2, NT-3, and PDGF-BB, dose-response curves were constructed using a $2 \mathrm{~d}$ survival assay and 125 cells per coverslip as described above. As mentioned previously, NT-3 and PDGF-BB when applied alone had only small, although significant, effects on Schwann cell 

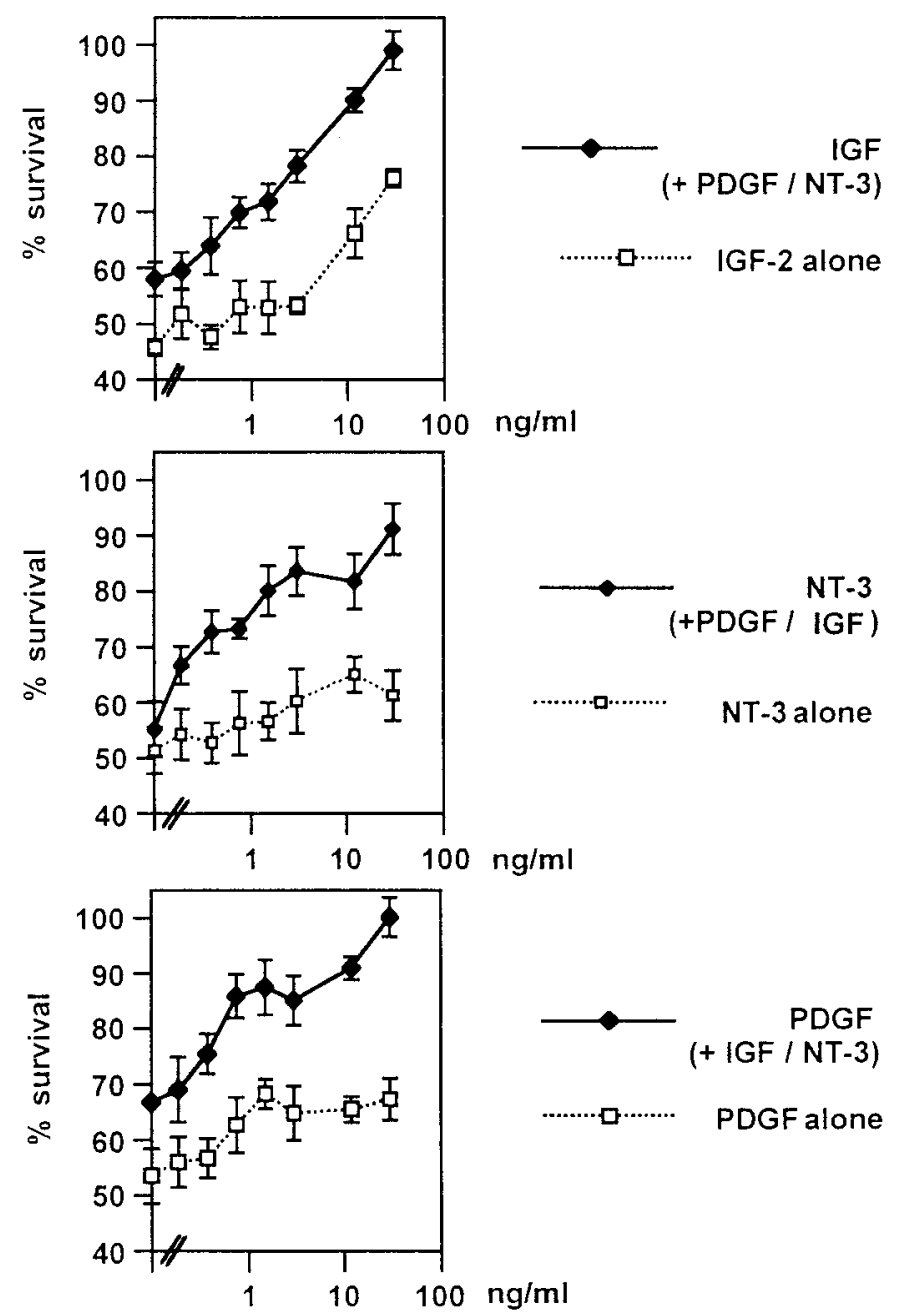

Figure 3. Dose-response curves of NT-3, IGF-2, and PDGF-BB alone and on the background of the other two factors. Note that each of these factors unambiguously promotes Schwann cell survival in a dosedependent manner provided the other two factors are present. Note that when applied singly at the concentration used in the minimal mixture (IGF-2, $1.6 \mathrm{ng} / \mathrm{ml}$; NT-3 and PDGF-BB, $0.8 \mathrm{ng} / \mathrm{ml}$ ), the effect of each factor is small, although the mixture supports full survival (see Results and Fig. 2B, first column from left) showing a synergistic action in promoting survival. The IGF-2 curve was constructed in the presence of PDGF-BB and NT-3 both at $0.2 \mathrm{ng} / \mathrm{ml}$. The NT-3 curve was constructed in the presence of PDGF-BB at $0.2 \mathrm{ng} / \mathrm{ml}$ and $\mathrm{IGF}-2$ at $0.4 \mathrm{ng} / \mathrm{ml}$. The PDGF-BB curve was constructed in the presence of NT-3 at $0.2 \mathrm{ng} / \mathrm{ml}$ and IGF-2 at $0.4 \mathrm{ng} / \mathrm{ml}$. PORN substrate, 125 cells per coverslip, $2 \mathrm{~d}$ assay.

survival, even at high concentrations (Fig. 3). IGF-2 alone was more effective. At the highest concentration tested it supported the survival of $\sim 75 \%$ of the cells present at the start of the experiment. Because at this time point $(2 \mathrm{~d}) \sim 45 \%$ of the cells survived even without added factors, this means that IGF-2 could rescue just more than half of the cells that would otherwise die. We then examined the dose-response relationship for each of these factors under conditions in which all three are present, as predicted in the conditioned medium. To reveal clearly the survival-promoting effect of each factor, it was titrated on the background of a constant concentration of the other two, which was four times lower than that in the minimal mixture of IGF-2 (1.6 ng/ml), NT-3, and PDGF-BB (0.8 ng/ml). The dosedependent effects of these factors are shown in Figure 3. Taken together these experiments show that a combination of IGF-2,
NT-3, and PDGF-BB supports Schwann cell survival in a manner predicted by the experiments with blocking antibodies. This strongly supports the notion that these factors are key components of an autocrine Schwann cell survival signal.

\section{Conditioned medium and IGF-2, NT-3, and PDGF-BB show a similar bioactivity profile: comparison with $\beta$-neuregulin-1}

Apart from the present work, the only defined factor shown to support the survival of neonatal Schwann cells is $\beta$-neuregulin-1 (Syroid et al., 1996; Trachtenberg and Thompson, 1996). Because low levels of neuregulin mRNA can also be detected in Schwann cells (Raabe et al., 1996), we examined $\beta$-neuregulin-1 as a candidate component of the autocrine survival loop. We confirmed that $\beta$-neuregulin-1 supported full survival of neonatal Schwann cells in the survival assay used above, i.e., with a $2 \mathrm{~d}$ assay 125 cells plated on PORN coated coverslips in simple defined medium. This shows that the $\beta$-neuregulin- 1 survival signal is independent of the additional presence of supplements to the medium, serum, laminin, or autocrine factors (Fig. 4A). However, 8-10 $\mathrm{ng} / \mathrm{ml} \beta$-neuregulin- 1 was required for maximum effect, which was a 5-10 times higher concentration than that needed for maximal survival support of E14 Schwann cell precursors (see Fig. 9B; Dong et al., 1995). Soluble ErbB4 receptor protein, which specifically binds to and neutralizes neuregulin, had no effect on survival in conditioned medium or in IGF-2, NT-3, and PDGF-BB, although this protein reduced cell numbers in $\beta$-neuregulin- 1 in a dose-dependent way (Fig. $4 A$ ). Conversely, blocking antibodies against IGF, NT-3, and PDGF-BB, used at the same concentrations as those applied to conditioned media (Fig. 2A), had no significant effect on neuregulin-mediated Schwann cell survival in this assay (Fig. 4B).

Additional tests revealed further differences between $\beta$-neuregulin-1 and Schwann cell conditioned medium. First, using supplemented defined medium, we compared the effects of conditioned medium, IGF-2, NT-3, and PDGF-BB, and $\beta$-neuregulin-1 on DNA synthesis in Schwann cells immunopanned from neonatal nerves. In a $2 \mathrm{~d}$ mitogen assay on 125 - and 2000-cell cultures using the BrdU method, $1 \%$ of cells were labeled in the presence of conditioned medium, $30 \%$ were labeled in the presence of $8 \mathrm{ng} / \mathrm{ml}$ neuregulin- $\beta 1$, and $2.5 \%$ were labeled in the presence of the minimum mixture of IGF-2, NT-3, and PDGF-BB. Survival registered as $100 \%$ in each of these experiments. These differences are unlikely to be explained by the use of inappropriate concentrations, because many cells showed BrdU labeling in the presence of neuregulin- $\beta 1$ even at concentrations lower than that required for full survival and, conversely, in the presence of IGF, NT-3, and PDGF-BB, the proportion of BrdU-labeled cells remained at $1 \%$ even if the concentration of all three factors was increased threefold. Thus, in conditioned medium and in IGF-2, NT-3, and PDGF-BB, cells survive without proliferating, under the present experimental conditions, whereas in $\beta$-neuregulin-1 promotion of survival and DNA synthesis occur at similar concentrations. Second, we (on the basis of simple defined medium) examined the stimulation of DNA synthesis in Swiss 3 T3 fibroblasts. Again, conditioned medium and the minimum mixture of IGF-2, NT-3, and PDGF-BB acted in a similar way, generating nuclear labeling in 81 and $53 \%$ of the cells, respectively. In contrast, the proportion of cells labeled in the presence of $8 \mathrm{ng} / \mathrm{ml}$ neuregulin- $\beta 1$ remained at the same level as the controls, $12 \%$. In one experiment involving triplicate coverslips we compared the effects on DNA synthesis of adding 4 

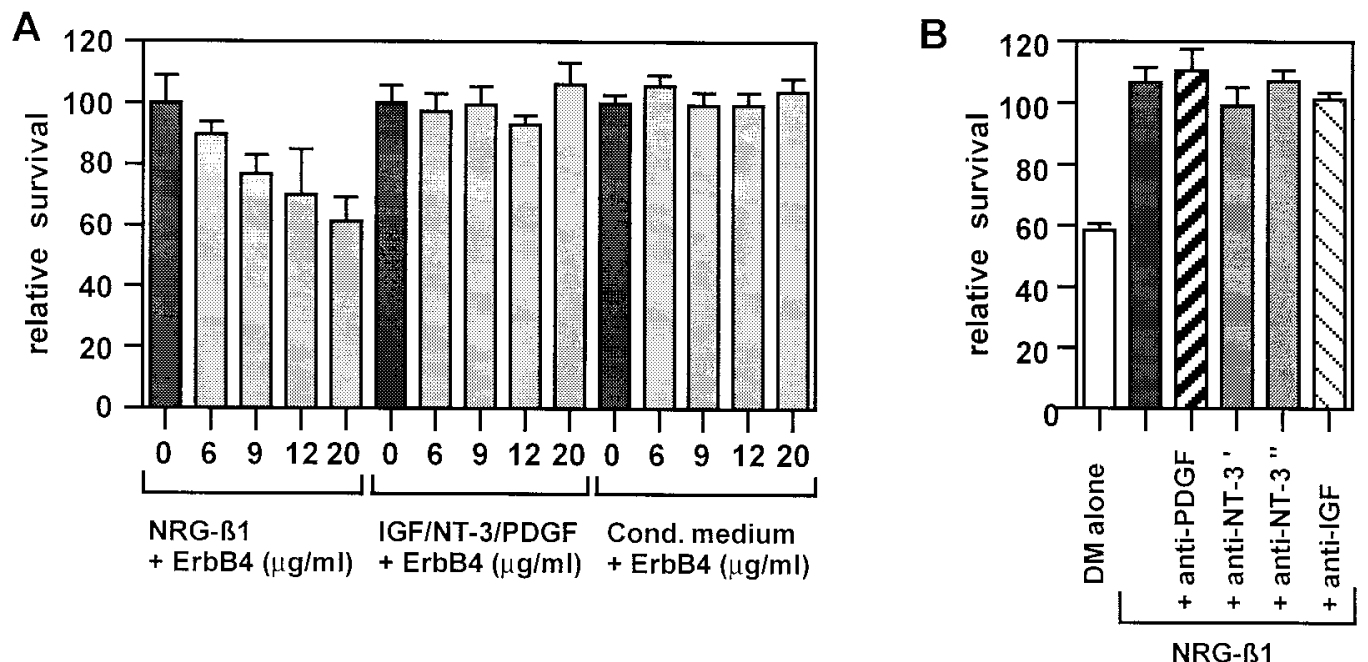

Figure 4. $\quad \beta$-Neuregulins support Schwann cell survival but are unlikely to be a major component of the survival signal in conditioned media. $A$, A soluble form of the $\beta$-neuregulin-1 receptor ErbB4 inhibits $\beta$-neuregulin-1-mediated survival but has no effect on survival mediated by the minimal mixture of IGF-2, NT-3, and PDGF-BB or conditioned medium (dilution, 1:10). Note that for direct comparison, cell number at the end of the assay (2 d) in $\beta$-neuregulin-1 alone is arbitrarily set at $100 \%$. Cell number in the presence of $\beta$-neuregulin- 1 plus added ErbB4 is normalized to this value to obtain relative survival. $N R G$ - $\beta 1, \beta$-Neuregulin- $1,8 \mathrm{ng} / \mathrm{ml}$. PORN substrate, 125 cells per coverslip, $2 \mathrm{~d}$ assay. $B$, $\beta$-Neuregulin-mediated survival is unaffected by neutralizing antibodies to IGF, NT-3, or PDGF-BB. DM, Simple defined medium; NRG- $\beta 1$, $\beta$-neuregulin- $1,8 \mathrm{ng} / \mathrm{ml}$. For anti-NT-3' and anti-NT-3" see legend to Figure $2 A$; anti-IGF, IGF antibody SM1.2. The antibodies were applied at the same concentrations as those used to inhibit activity in conditioned media. PORN substrate, 125 cells per coverslip, $2 \mathrm{~d}$ assay.

\begin{tabular}{lcccc}
\hline Table 1. Cell survival and proliferation & & & & \\
Medium & $\begin{array}{l}\text { Schwann } \\
\text { cell survival }\end{array}$ & $\begin{array}{l}\text { Precursor } \\
\text { cell survival }\end{array}$ & $\begin{array}{l}\text { Schwann cell } \\
\text { proliferation }\end{array}$ & $\begin{array}{l}\text { Fibroblast } \\
\text { proliferation }\end{array}$ \\
\hline IGF NT-3, PDGF-BB & + & - & - & + \\
Conditioned medium & + & - & - & + \\
$\beta$-Neuregulin-1 & + & + & + & - \\
\hline
\end{tabular}

$\mu \mathrm{M}$ forskolin to conditioned medium on the one hand and to the minimal mixture of IGF-2, NT-3, and PDGF-BB on the other. Forskolin was added to a combination of FGF-2 $(10 \mathrm{ng} / \mathrm{ml})$ and IGF-1 $(50 \mathrm{ng} / \mathrm{ml})$ as a positive control, because these factors are established Schwann cell mitogens in the presence of forskolin. The experiment was done in simple defined medium on the PORN surface. In the case of both conditioned medium and IGF-2, NT-3, and PDGF-BB, addition of forskolin increased the percentage of BrdU-labeled nuclei by approximately threefold, although the proportions of BrdU-labeled nuclei always remained $\leq 5 \%$. In contrast, FGF-2 and IGF-1 plus forskolin provided a strong mitogenic stimulus resulting in $\geq 65 \%$ of nuclei being labeled. These preliminary experiments suggest a further similarity between conditioned medium and the mixture of IGF-2, NT-3, and PDGF-BB, because neither of these are converted to a strong mitogen with addition of forskolin. It should be noted that there is strong evidence that Schwann cell conditioned medium contains an activity that inhibits Schwann cell DNA synthesis (Muir et al., 1990; Eccleston et al., 1991). This activity is, of course, not present in the minimal mixture, and this difference will complicate any further comparison of the mitogenic effects of conditioned medium and IGF-2, NT-3, and PDGF-BB.

Additional parallels between the actions of conditioned medium and IGF-2, NT-3, and PDGF-BB and differences between these agents and $\beta$-neuregulin- 1 were revealed by examining intracellular signaling pathways and the survival response of E14
Schwann cell precursors (see below). Together, these comparisons, summarized in Table 1, underscore the similarities between Schwann cell conditioned medium and IGF-2, NT-3, and PDGF-BB and render it unlikely that $\beta$-neuregulin- 1 is a major component of the autocrine survival mechanism in neonatal Schwann cells.

\section{Conditioned medium and the mixture of IGF-2, NT-3, and PDGF-BB transduce their survival signal via the MAP kinase pathway}

To elucidate the intracellular pathways used by conditioned medium and IGF-2, NT-3, and PDGF-BB, we investigated one of the main pathways involved in growth factor signaling from cell surface tyrosine kinase receptor proteins to the nucleus, the MAP kinase pathway. Schwann cells were plated at 125 cells per coverslip on PORN substrate in simple defined medium, preincubated with MEK 1/2 inhibitor PD98059 for $1 \mathrm{hr}$, and subsequently cultured with the inhibitor in conditioned medium, the mixture of IGF-2, NT-3, and PDGF-BB, or $\beta$-neuregulin- 1 for 48 hr. The inhibitor PD98059 has previously been shown to block MEK $1\left(\mathrm{IC}_{50}, 5-10 \mu \mathrm{M}\right)$ and MEK $2\left(\mathrm{IC}_{50}, 50 \mu \mathrm{M}\right)$ phosphorylation and therefore activation in vitro (Alessi et al., 1995; Dudley et al., 1995; Pang et al., 1995). Both conditioned medium and IGF-2, NT-3, and PDGF-BB showed a strong dose-dependent response to the MEK 1/2 inhibition. In contrast, $\beta$-neuregulin-1mediated survival was not affected by disruption of the MAP 


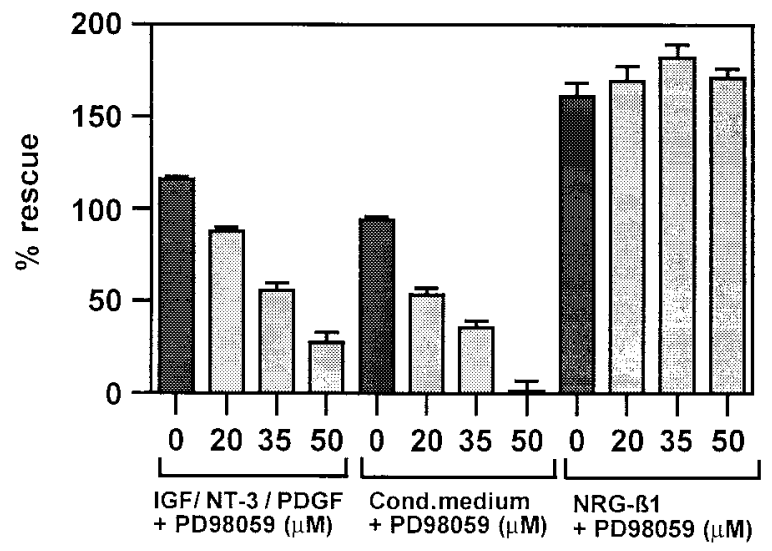

Figure 5. Survival in conditioned medium or in IGF-2, NT-3, and PDGF-BB depends on MAP kinase activation, but survival in $\beta$-neuregulin-1 is MAP kinase-independent. The graph shows the effect of blocking the MAP kinase pathway (using 20, 35, or $50 \mu \mathrm{M}$ PD98059) on survival under three different conditions: in the minimal mixture of IGF-2, NT-3, and PDGF-BB, in conditioned medium at a dilution of 1:10 (Cond.medium), and in $\beta$-neuregulin-1 at $8 \mathrm{ng} / \mathrm{ml}(N R G-\beta 1)$. Note that PD98059 has no effect on cell numbers in $\beta$-neuregulin. The number is higher at the end of the assay than the number of cells initially plated because of the mitogenic effect of $\beta$-neuregulin-1. The experiment was done in simple defined medium using PORN substrate, 125 cells per coverslip, and a $2 \mathrm{~d}$ assay.

kinase signaling cascade even at the highest inhibitor concentrations used (Fig. 5). In control experiments, using high-density cultures plated on laminin substrate in supplemented defined medium, we showed that $\beta$-neuregulin-1-induced Schwann cell proliferation was reduced by 50\% in the presence of PD98059 (50 $\mu \mathrm{M})$, in agreement with reports that $\beta$-neuregulin- 1 can activate MAP kinase kinase in Schwann cells (Kim et al., 1997; Fiddes et al., 1998).

These experiments show that conditioned medium and IGF-2, NT-3, and PDGF-BB rely on the MAP kinase pathway for mediating survival. Although $\beta$-neuregulin-1 can activate MAP kinase, this is not required for survival signaling under the conditions used here.

\section{The candidate autocrine ligands and the corresponding receptors are expressed in Schwann cells in vitro and in vivo}

If IGF-2 (or IGF-1), NT-3, and PDGF-BB are autocrine survival signals, they should be expressed in newborn nerves and in vitro in Schwann cells used to produce conditioned medium. To test this, we used semiquantitative RT-PCR to compare IGF-1, IGF-2, NT-3, and PDGF-B mRNA and their respective receptor mRNA expression in newborn nerves and in immunopanned newborn Schwann cells. As illustrated in Figure $6 A$, the different factors and their corresponding receptors were detectable in both newborn sciatic nerves and immunopanned Schwann cells. The relative amount of mRNA for PDGF-BB, PDGF- $\beta$ receptor, IGF-2, and IGF-RII in both newborn nerves and immunopanned cells was higher than those for NT-3, TrkC, IGF-1, and IGF-RI receptor, because 10 times less cDNA was necessary to detect the former. Furthermore, the levels of IGF-1 mRNA were lower in cultured cells than in the nerve, because five times more cDNA from cultured cells was required for the detection of a comparable signal from the two tissues. This is consistent with IGF-2 being more important than IGF-1 in the conditioned medium, as suggested by the antibody blocking experiments.

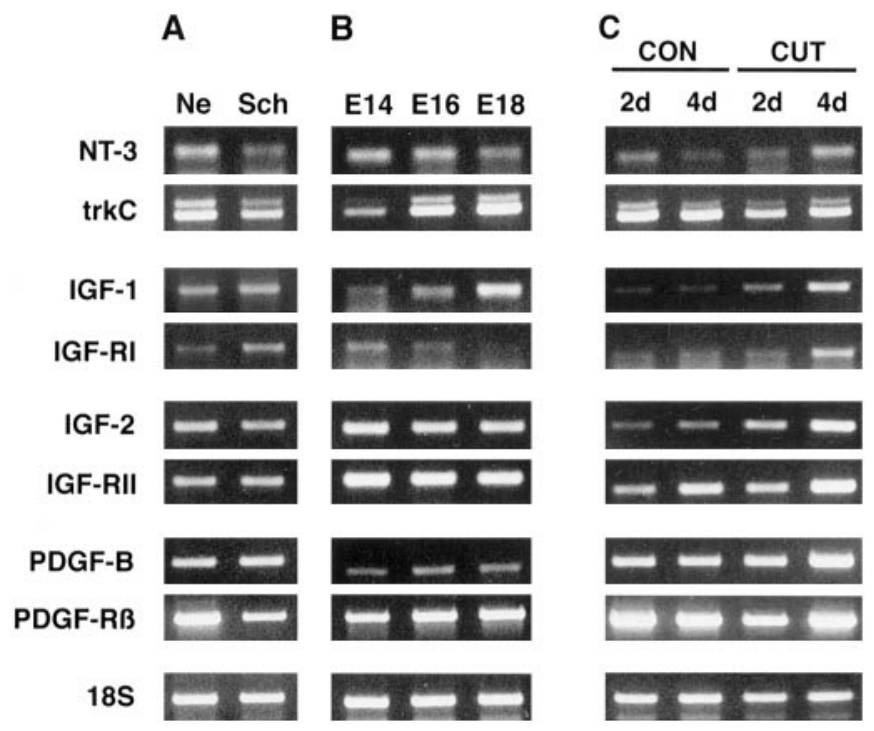

Figure 6. Semiquantitative RT-PCR analysis of the putative autocrine factors and their respective receptor mRNAs during development, in culture, and after nerve transection. $A$, RT-PCR on neonatal sciatic nerve $(\mathrm{Ne})$ and Schwann cells cultured from neonatal nerves $(\mathrm{Sch})$. Examination of IGF-1 (43 cycles), IGF-2 (28 cycles), PDGF-B (33 cycles), and NT-3 (48 cycles) and their corresponding receptors IGF-RI (45 cycles), IGFRII (33 cycles), PDGF-R $\beta$ (33 cycles), and TrkC (36 cycles) reveals the presence of all mRNAs in newborn nerve as well as Schwann cells in culture. B, These mRNAs are expressed in E18 nerves (immature Schwann cells) but also earlier in embryonic development at E14 (precursor stage) and E16 (a transition point between precursors and immature Schwann cells). The cycle numbers for each primer pair were 33 cycles for IGF-1, 27 cycles for IGF-2, 46 cycles for NT-3, and 33 cycles for the TrkC receptor. For all other primer pairs the cycle numbers were identical to those listed in $A$. $C$, After nerve transection, mRNAs for all factors and their receptors are expressed at the levels that are broadly comparable to the contralateral control side. $C O N$, Normal nerves of 2and 4-d-old rats; $C U T$, the distal stump of 2- and 4-d-old rats 2 and $4 \mathrm{~d}$ after transection performed at birth. Cycle numbers were 30 for IGF-1, 27 for IGF-2, 40 for NT-3, and 35 for TrkC. For PDGF-B and PDGF-R $\beta 34$ cycles were done. Again, 45 cycles were run for IGF-RI, and 33 were run for IGF-RII.

IGF-2, NT-3, and PDGF-BB as well as TrkC and PDGF- $\beta$ receptors were also detected in Schwann cells by immunohistochemistry (Fig. 7). In nerves from 9 d- and 4-week-old rats that were teased before immunolabeling for optimum resolution, immunolabeling for all three ligands was seen in Schwann cells. In myelinated fibers, immunolabeling was absent from myelin and axons; the labeling was strongest in the perinuclear areas but frequently extended along the outer cytoplasmic collar. TrkC and PDGF- $\beta$ receptor immunoreactivity showed comparable localization, whereas IGF-RI receptor antibodies bound more weakly in these preparations. Similar TrkC immunolabeling in the outer cytoplasmic collar of myelinating cells has recently been reported using other TrkC antibodies (Ruggiero et al., 1998). When this immunostaining experiment was repeated using the distal stump of nerves from 4-week-old animals that had been transected $3 \mathrm{~d}$ previously, IGF-2 immunolabeling was noticeably stronger (Fig. $7 B$ ). In the cultured cells, the IGF-RI antibodies again bound only weakly, although essentially all cells showed detectable labeling. Previously, however, IGF-RI has been clearly localized on all Schwann cells in cultures from neonatal rat nerves using an alternative antibody (Schumacher et al., 1993). IGF-RII receptors are also expressed by essentially all Schwann cells in vitro (Stewart et al., 1996). Although the IGF-2 antibodies strongly labeled the 
IGF-2
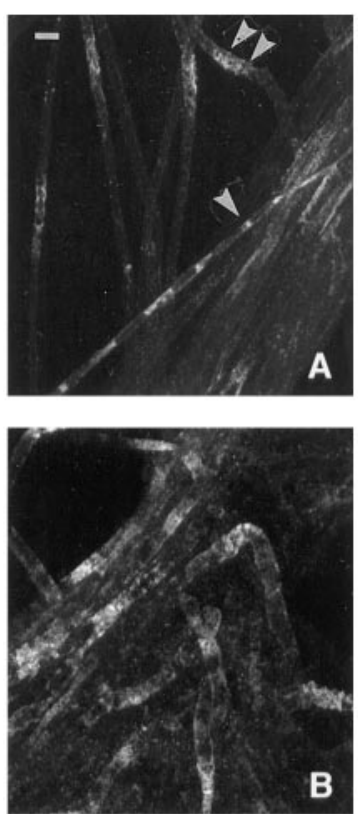

NT-3
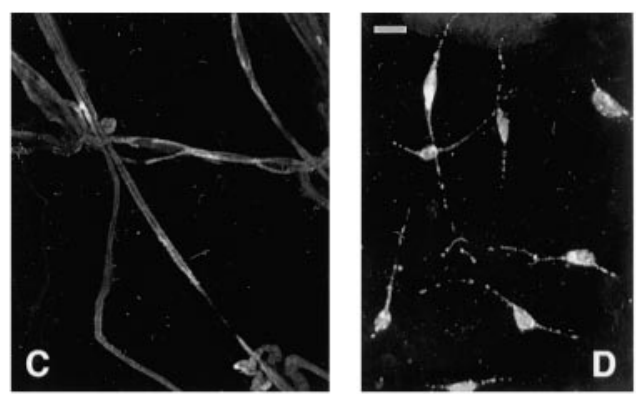

D

\section{PDGF-BB}

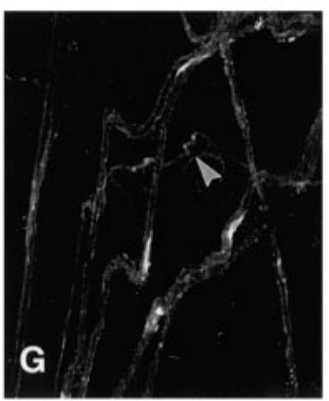

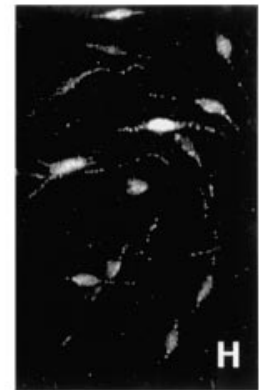

TrkC
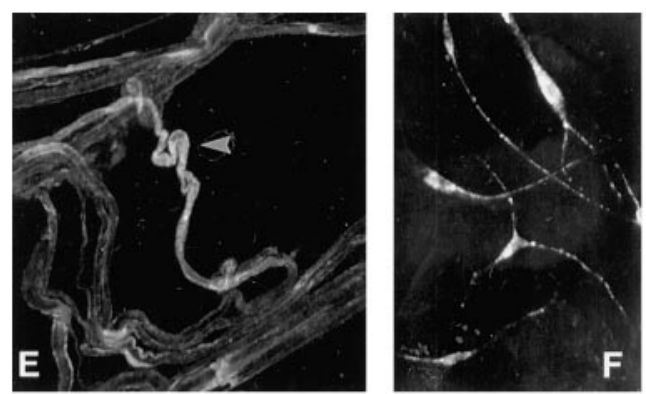
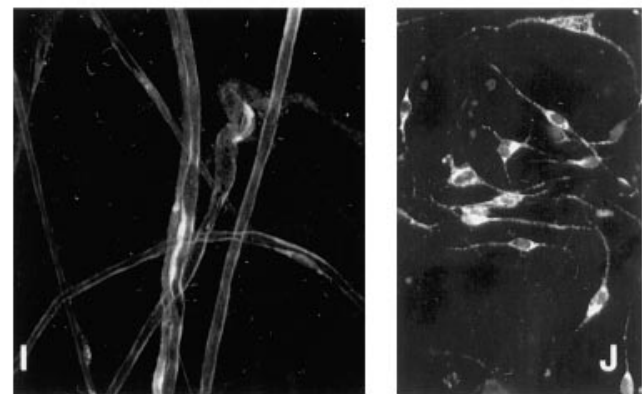

Figure 7. Immunohistochemical experiments on teased nerves and cultured Schwann cells. $A-C, E, G, I$, Teased nerves from 4-week-old rats labeled by antibodies as indicated. The nerve shown in $B$ is the distal stump of a nerve that was transected $3 \mathrm{~d}$ before immunolabeling. Note that labeling is more intense and widespread in $B$ than in $A$. In myelinated fibers, immunolabeling is generally most intense in nuclear regions (examples indicated with double arrowheads) but is also seen in the outer cytoplasmic collar; this can be seen most clearly in $E$, $G$, and $I$. Examples of unmyelinated fibers are indicated with single arrowheads. $D, F, H, J$, Cultured Schwann cells made from 7-d-old rats. In all cases speckled immunolabeling was seen in the cell body region and in cellular processes. Scale bars $(A, D), 20 \mu \mathrm{m}$.

cells in teased nerves, they were not suitable for use on cultured cells, because they work on unfixed, frozen tissue only (manufacturer's information; our unpublished observations). The NT-3, PDGF-BB, TrkC, and PDGF- $\beta$ receptor antibodies clearly labeled the cultured cells. All the cells bound PDGF-BB antibodies; $\sim 10 \%$ of Schwann cells showed weak or no labeling with PDGF- $\beta$ receptor antibodies, whereas NT-3 and TrkC antibodies bound to an intermediate number of cells.

\section{NT-3, IGF-1, IGF-2, and PDGF-B mRNA and the corresponding receptor mRNA are expressed in Schwann cell precursors and embryonic Schwann cells}

Because Schwann cell precursors did not show autocrine rescue and were unresponsive to the IGF-2, NT-3, and PDGF-BB combination of growth factors, it was possible that the precursors failed to express some or all of the relevant growth factor or growth factor receptor genes.

To test this we investigated, using semiquantitative RT-PCR, the regulation of IGF-1, IGF-2, NT-3, and PDGF-B mRNA expression and their corresponding receptors in embryonic sciatic nerve between E14 (precursor stage) and E18 (Schwann cell stage). As expected, all the factors and their receptors were expressed at E18 (Fig. 6B). However, all nine mRNAs could also be detected in E14 nerves. It remains possible that mRNA expression is not accompanied by protein expression in every case. Alternatively, intracellular transduction of potential survival signals may differ between precursors and Schwann cells.
NT-3, IGF-1, IGF-2, and PDGF-B mRNA continue to be expressed after neonatal sciatic nerve transection

In vivo, most neonatal Schwann cells survive after axotomy. If the autocrine survival loop including NT-3, IGF-1 and -2, and PDGF-B is involved in this process, the mRNA encoding these factors and their receptors should continue to be expressed, perhaps at higher levels, after axotomy. To test this, we used a semiquantitative RT-PCR analysis of the different factors and their corresponding receptors 2 and $4 \mathrm{~d}$ after sciatic nerve transection in newborn rats. Comparison of mRNA levels in the distal part of the transected nerve and in the contralateral nerve showed that eight genes continued to be expressed $4 \mathrm{~d}$ after surgery (Fig. $6 C$ ). Although the limitations of the RT-PCR method should be kept in mind, there was an indication of upregulation of mRNAs for all of those genes except TrkC and PDGF- $\beta$. Taken together these results are consistent with the three identified constituents of the survival mixture being involved in the establishment of an autocrine loop in vivo.

\section{Longer-term survival requires both laminin and autocrine signals}

Although the experiments described above have made a strong case for the mixture of IGF-2, NT-3, and PDGF-BB as an autocrine Schwann cell survival signal, most of the observations have been made within the first $2 \mathrm{~d}$ in culture. We now asked whether the autocrine mechanisms outlined above could support Schwann cell survival for a longer time. Surprisingly, we found 

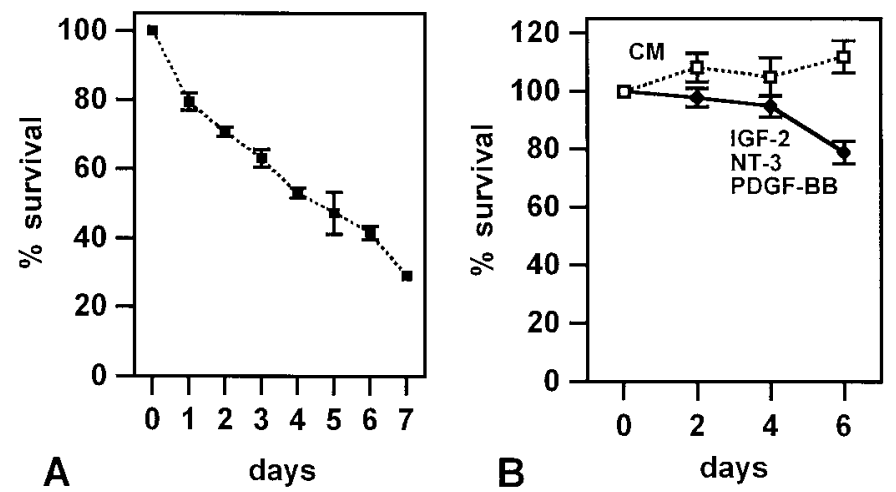

Figure 8. In the presence of autocrine signals, laminin promotes longterm survival. $A$, In sparse cultures, Schwann cells die on laminin substrate. Laminin substrate, 125 cells per coverslip. $B$, Laminin promotes longer-term survival in the minimal mixture of IGF-2, NT-3, and PDGF-BB and supports full survival for at least $6 \mathrm{~d}$ in the presence of conditioned medium ( $C M$; dilution, 1:10). Laminin substrate, 125 cells per coverslip.

that neither the Schwann cell-derived survival factors in conditioned media nor the minimal IGF-2, NT-3, and PDGF-BB combination supported survival much beyond $2 \mathrm{~d}$ under the conditions of our assay, although the growth factor combination was more effective than the conditioned medium (data not shown). In agreement with this, even in dense Schwann cell cultures survival deteriorated after $2 \mathrm{~d}$ (data not shown). These experiments highlighted yet again similarities of action between the Schwann cell-derived factors and IGF, NT-3, and PDGF-BB. More importantly, however, they indicated that the autocrine survival loop alone may not be sufficient to guarantee Schwann cell survival and pointed to the presence of a second survival signal in cut nerves. We tested whether this could be laminin, a main component of the Schwann cell basal lamina and a molecule implicated in regulation of Schwann cell development (Bunge, 1993; Martini, 1994). We plated cells on laminin substrate at 125 cells per coverslip using simple defined medium in the absence of growth factors and compared their survival with that seen previously on PORN substrate (see Fig. $1 B$ ). This showed laminin alone to be ineffective in maintaining Schwann cell survival (Fig. 8A). Marked improvement in longer-term survival was seen when the minimal mixture of IGF-2, NT-3, and PDGF-BB was applied in the presence of laminin, although some deterioration was seen between days 4 and 6 . When we tested the effects of combining the use of a laminin substrate with exposure to Schwann cell conditioned media, we found that full survival was maintained for at least $6 \mathrm{~d}$ in vitro, the longest period tested (Fig. $8 B$ ). Under these conditions the cells assumed a markedly elongated morphology.

We therefore suggest that Schwann cell survival in cut nerves is ensured by synergistic interactions between the basal lamina that surrounds denervated Schwann cells in vivo and an autocrine signal. Together, this constitutes a signal capable of suppressing Schwann cell death for a considerable time, although Schwann cell numbers in distal stumps gradually decline after transection, and most cells are eventually lost (Weinberg and Spencer, 1978).

\section{Autocrine survival support is absent in Schwann cell precursors and develops as a component of the Schwann cell phenotype}

Previously we showed that Schwann cell precursors died during $20 \mathrm{hr}$ after plating in the absence of neurons, whereas Schwann
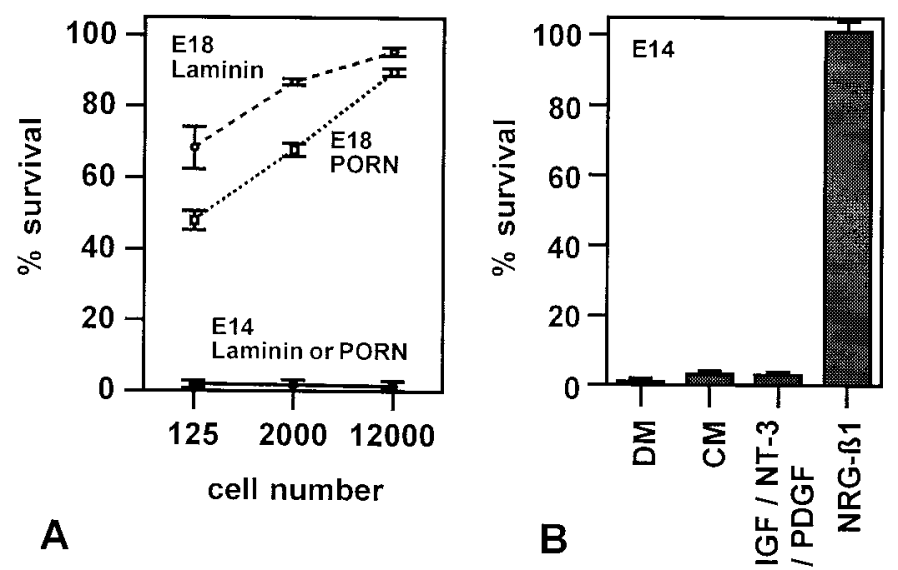

Figure 9. The emergence of an autocrine survival circuit coincides with the generation of Schwann cells from precursors. A, Essentially all E14 precursors die irrespective of plating density, whereas the survival of immature Schwann cells from E18 nerves is density-dependent. Identical results were obtained on laminin or PORN substrates in experiments with precursors. E18 Schwann cells die more slowly on laminin than on PORN. Therefore, at the $2 \mathrm{~d}$ time points shown here, more cells are still alive at each density point on laminin compared with PORN substrates. One day assay for E14 precursors, $2 \mathrm{~d}$ assay for E18 Schwann cells. B, E14 Schwann cell precursors cannot be rescued by Schwann cell conditioned medium or by IGF-2, NT-3, and PDGF-BB. $\beta$-Neuregulin, an established precursor survival factor, is included as a positive control. $D M$, Simple defined medium; $C M$, Schwann cell conditioned medium at a dilution of 1:10. IGF-2, NT-3, and PDGF-BB were at the minimal concentrations, and $\beta$-neuregulin- 1 was at $2 \mathrm{ng} / \mathrm{ml}$. PORN substrate, $1 \mathrm{~d}$ assay. Identical results were obtained when the experiments shown in $B$ were performed in supplemented defined medium and when the experiments were performed on laminin substrate (data not shown).

cells from newborn animals survived when plated under similar conditions (Jessen et al., 1994). Schwann cell survival in these experiments can now be explained by a combination of relatively high cell density and the use of laminin, whereas the precursor death indicated that these cells were unable to support their own survival. This raised the possibility that the precursor-Schwann cell transition, which takes place in the sciatic nerve between E14-E15 and E17-E18, included the development of autocrine survival loops. To test this we used precursors from E14 nerves and cells from E18 nerves, i.e., early embryonic Schwann cells, in density-survival experiments under conditions identical to those used for newborn cells (see Fig. 1A). It was found that E14 precursors died even at very high densities, whereas E18 Schwann cells showed a relationship between density and survival that was comparable to that found with newborn cells (Fig. 9A). Similar results were obtained on laminin and PORN substrates. We also tested whether precursor death could be prevented either by Schwann cell conditioned medium or by the mixture of IGF-2, NT-3, and PDGF-BB. $\beta$-Neuregulin, an established precursor survival factor, was used as a positive control (Dong et al., 1995). It was found that neither the conditioned medium nor the factor combination supported precursor survival (Fig. 9B). Similar results were obtained when the concentration of all three factors in the mixture was increased threefold (data not shown). Both conditioned medium and IGF-2, NT-3, and PDGF-BB supported full survival of E18 cells (data not shown).

Together these experiments showed that the establishment of the autocrine mode of support coincides with the formation of Schwann cells from precursors and that these two cell types differ in the survival signals to which they respond. 


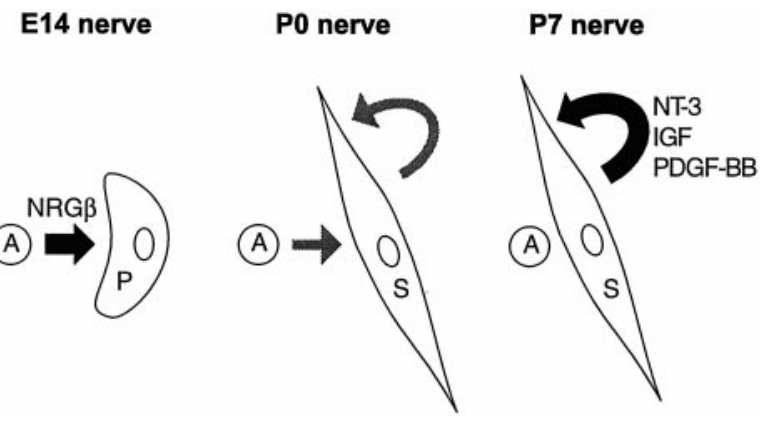

Figure 10. From paracrine signals to autocrine loops: the proposed changes in survival regulation during Schwann cell development. The survival of E14 Schwann cell precursors is regulated in a paracrine manner by axon-derived $\beta$-neuregulin-1. During development, Schwann cells establish autocrine circuits, which, in neonatal nerves, act in parallel with the axonal signal. During Schwann cell maturation the autocrine signal becomes sufficient to prevent Schwann cell death in the absence of axons. The factors IGF, NT-3, and PDGF-BB have been shown to be major components of this autocrine signal in Schwann cells from 7-d-old nerves. In vivo experiments indicate that at this date loss of axonal contact after nerve transection no longer triggers significant Schwann cell death (Z. Dong, R. Mirsky, and K. R. Jessen, unpublished observations). A, Axons; $P$, Schwann cell precursors; $S$, Schwann cells.

\section{DISCUSSION}

In this work we show that Schwann cells acquire the ability to survive without axons by establishing an autocrine survival loop. This mechanism is absent from Schwann cell precursors. We also identify IGFs (probably IGF-2), NT-3, and PDGF-BB as important components of this autocrine survival signal. By ensuring that Schwann cells survive even in the absence of axons, the autocrine signal is likely to be of crucial importance for repair in the peripheral nervous system, because significant axon regrowth depends on living Schwann cells in the denervated distal part of damaged nerves (Fawcett and Keynes, 1990). The demonstration that Schwann cells can secrete biologically relevant quantities of IGFs, NT-3, and PDGF-BB also has considerable implications for cellular communication in the developing nervous system, in view of the well documented effects of these factors, in particular IGFs and NT-3, on survival and differentiation of other cells, including neurons (Sara and Hall, 1990; Davies, 1996; Lewin and Barde, 1996; Feldman et al., 1997).

The present results show that E14 precursors, unlike Schwann cells, do not show density-dependent survival, nor can Schwann cell conditioned media rescue them from death. The survival of precursors therefore depends on extrinsic signals, which appear to come from axons (Dong et al., 1995; Meyer and Birchmeier, 1995; Ciutat et al., 1996; Riethmacher et al., 1997) (Fig. 10). The results also demonstrate that the ability for autocrine rescue develops as a part of the precursor-Schwann cell transition that takes place between E14-E15 and E17-E18. Nevertheless, Schwann cells probably continue to rely in part on axons for survival for a period that may last for up to several days after birth. This is indicated by two observations. Most importantly, transection of the sciatic nerve at birth triggers some increase in Schwann cell death in the distal stump, whereas this response is reduced in 5-d-old animals and absent in 20-d-old or older animals (Grinspan et al., 1996; Syroid et al., 1996). Additionally, we have noted that conditioned medium from cultures made from 7 -d-old nerves is severalfold more effective in supporting Schwann cell survival than is medium from cultures generated from newborn nerves, which may indicate a progressive increase in the effectiveness of the autocrine survival loops (data not shown). In the perinatal period, therefore, Schwann cells rely on a dual support system with survival signals coming both from axons and the cells themselves (Fig. 10).

The identification of IGF-2, NT-3, and PDGF-BB as components of the autocrine survival mixture relies on antibody neutralizing experiments, detailed mimicking of the survival activity in Schwann cell conditioned media by a combination of these factors in the approximate concentrations of $1.5 \mathrm{ng} / \mathrm{ml}$ (IGF) and $0.75 \mathrm{ng} / \mathrm{ml}$ (NT-3 and PDGF-BB), a similarity between this mixture and conditioned media with respect to regulation of survival and proliferation in Schwann cells, Schwann cell precursors, and fibroblasts, and the use of intracellular signaling pathways. Furthermore, we find that these factors and their receptors are expressed in perinatal and older Schwann cells and that their expression is maintained in transected newborn nerves as expected if they played a role in survival support in injured nerves. There is previous evidence for the expression of all of these factors and receptors in normal and transected peripheral nerves (Hardy et al., 1992; Funakoshi et al., 1993; Glazner et al., 1994; Offenhäuser et al., 1995; Pu et al., 1995; Cheng et al., 1996; Svenningsen and Kanje, 1996; Hammarberg et al., 1998). The present demonstration of a PDGF-BB autocrine loop confirms our previous conclusion using other methods, in which PDGF-BB was detected as an autocrine Schwann cell mitogen because of a different growth factor environment (Eccleston et al., 1990, 1993). The RT-PCR measurements show that all of the relevant genes are already expressed, at least at the mRNA level, in E14 precursors and therefore fail to provide a simple explanation for the absence of autocrine survival support and lack of effect of the IGF, NT-3, and PDGF-BB combination in these cells. We have not ascertained that expression of these mRNAs in precursors is in every case accompanied by protein expression. Another possible explanation would be the absence of effective signal transduction via receptors present on precursors, as seen in the case of PDGF receptors on newly formed oligodendrocytes (Hart et al., 1989, 1992).

To provide an effective rescue mechanism for Schwann cells after nerve injury, survival of these cells must be guaranteed for a time, although Schwann cells in distal stumps of cut nerves appear to have a limited lifespan (Weinberg and Spencer, 1978; Li et al., 1998; Terenghi et al., 1998). Our studies show that the autocrine signal, in synergy with extracellular matrix molecules such as laminin, is able to maintain cell survival in the medium term. A clue to the mechanism underlying this interaction might come from the observation that laminin, via integrins, activates the MAP kinase pathway (Wei et al., 1998), a pathway we find to be activated by IGF-2, NT-3, and PDGF-BB and conditioned medium and essential for survival signaling by these factors. It has been suggested that some of the effects of laminin on Schwann cells are mediated by activation of focal adhesion kinase (Fernandez-Valle et al., 1998).

Although, using a number of different criteria, the minimal mixture of IGF-2, NT-3, and PDGF-BB accounts very well for the activity in the Schwann cell conditioned medium, it should be borne in mind, first, that the conditions in our experiments are extremely simplified and, second, that the medium will contain a number of potential signaling molecules apart from the three we have identified. This includes, for instance, an activity that suppresses Schwann cell DNA synthesis (Muir et al., 1990; Eccleston et al., 1991). It is not unlikely that in vivo and/or under different culture conditions, other factors may play a part in autocrine 
Schwann cell signaling. In our experiments, a pointer to the involvement of additional factors is provided by the observation that longer-term (6 d) survival is more effectively promoted by laminin plus conditioned medium than by laminin plus the minimal mixture. This may suggest that, in addition to IGF-2, NT-3, and PDGF-BB, the conditioned medium contains other factors that are relevant for long-term Schwann cell survival. One of these could be LIF, because this factor is upregulated in denervated Schwann cells (Curtis et al., 1994; Kurek et al., 1996), and there is evidence that LIF is present in Schwann cell conditioned media (G. Tofaris, K. R. Jessen, and R. Mirsky, unpublished data). It should also be pointed out that most of the present experiments were performed on cells from young animals. It is possible that in older nerves individual components of the mixture we have identified might change or alter in relative importance.

$\beta$-Neuregulins are expressed by Schwann cells in culture, and there is evidence that they form a subliminal autocrine loop that can be revealed in the presence of applied mitogens and is involved in regulating proliferation (Raabe et al., 1996; Carroll et al., 1997; Rosenbaum et al., 1997). Although $\beta$-neuregulin-1 may well have some involvement in autocrine survival signaling, the data are not consistent with $\beta$-neuregulins forming a major component of the autocrine signal studied in the present work.

The present observations reveal a degree of similarity in how the survival of oligodendrocytes and Schwann cells is regulated, because IGFs, NT-3, and another form of PDGF, PDGF-AA, have all been implicated in the control of oligodendrocyte survival and development (Barres et al., 1992, 1993a,b). The means by which these factors are made available appear, however, to have developed along two different lines. In the oligodendrocyte lineage, they are thought to act in a paracrine manner, i.e., as signals from other cells, such as astrocytes or neurons, whereas the present work indicates that in the Schwann cells, their function is autocrine. From an evolutionary standpoint, this difference may relate to the greater risk of trauma to peripheral nerves compared with the CNS. It is likely that cells that rely on themselves for survival are less vulnerable to death during tissue damage than cells that rely on their neighbors.

\section{REFERENCES}

Alessi DR, Cuenda A, Cohen P, Dudley DT, Saltiel AR (1995) PD 098059 is a specific inhibitor of the activation of mitogen-activated protein kinase kinase in vitro and in vivo. $\mathrm{J}$ Biol Chem 270:27489-27494.

Barres BA, Hart IK, Coles HSR, Burne JF, Voyvodic JT, Richardson WD, Raff MC (1992) Cell death and control of cell survival in the oligodendrocyte lineage. Cell 70:31-46.

Barres BA, Jacobson MD, Schmid R, Sendtner M, Raff MC (1993a) Does oligodendrocyte survival depend on axons? Curr Biol 3:489-497.

Barres BA, Schmid R, Sendtner M, Raff MC (1993b) Multiple extracellular signals are required for long-term oligodendrocyte survival. Development 118:283-295.

Bell GI, Stempien MM, Fong NM, Rall LB (1986) Sequences of liver cDNAs encoding two different mouse insulin-like growth factor I precursors. Nucleic Acids Res 14:7873-7882.

Blanchard AD, Sinanan A, Parmantier E, Zwart R, Broos L, Meijer D, Meier C, Jessen KR, Mirsky R (1996) Oct-6 (SCIP/Tst-1) is expressed in Schwann cell precursors, embryonic Schwann cells, and postnatal myelinating Schwann cells: comparison with Oct-1, Krox-20, and Pax-3. J Neurosci Res 46:630-640.

Brill G, Kahane N, Carmeli C, von Schack D, Barde YA, Kalcheim C (1995) Epithelial-mesenchymal conversion of dermatome progenitors requires neural tube-derived signals: characterization of the role of Neurotrophin-3. Development 121:2583-2594.

Bunge RP (1993) Expanding roles for the Schwann cell: ensheathment, myelination, trophism and regeneration. Curr Opin Neurobiol 3:805-809.

Carroll SL, Miller ML, Frohnert PW, Kim SS, Corbett JA (1997) Expression of neuregulins and their putative receptors, ErbB2 and ErbB3, is induced during Wallerian degeneration. J Neurosci 17:1642-1659.

Cheng HL, Randolph A, Yee D, Delafontaine P, Tennekoon G, Feldman EL (1996) Characterization of insulin-like growth factor-I and its receptor and binding proteins in transected nerves and cultured Schwann cells. J Neurochem 66:525-536.

Ciutat D, Calderó J, Oppenheim RW, Esquerda JE (1996) Schwann cell apoptosis during normal development and after axonal degeneration induced by neurotoxins in the chick embryo. J Neurosci 16:3979-3990.

Curtis R, Scherer SS, Somogyi R, Adryan KM, Ip NY, Zhu Y, Lindsay RM, DiStefano PS (1994) Retrograde axonal transport of LIF is increased by peripheral nerve injury: correlation with increased LIF expression in distal nerve. Neuron 12:191-204.

Davies AM (1996) The neurotrophic hypothesis: where does it stand? Philos Trans R Soc Lond B Biol Sci 351:389-394.

Dong Z, Brennan A, Liu N, Yarden Y, Lefkowitz G, Mirsky R, Jessen KR (1995) Neu differentiation factor is a neuron-glia signal and regulates survival, proliferation and maturation of rat Schwann cell precursors. Neuron 15:585-596.

Dong Z, Dean C, Walters JE, Mirsky R, Jessen KR (1997) Response of Schwann cells to mitogens in vitro is determined by pre-exposure to serum, time in vitro, and developmental age. Glia 20:219-230.

Dudley DT, Pang L, Decker SJ, Bridges AJ, Saltiel AR (1995) A synthetic inhibitor of the mitogen-activated protein kinase cascade. Proc Natl Acad Sci USA 92:7686-7689.

Eccleston PA, Collarini EJ, Jessen KR, Mirsky R, Richardson WD (1990) Schwann cells secrete a PDGF-like factor: evidence for an autocrine growth mechanism involving PDGF. Eur J Neurosci 2:985-992.

Eccleston PA, Mirsky R, Jessen KR (1991) Spontaneous immortalisation of Schwann cells in culture: short-term cultured Schwann cells secrete growth inhibitory activity. Development 112:33-42.

Eccleston PA, Funa K, Heldin CH (1993) Expression of platelet-derived growth factor (PDGF) and PDGF alpha- and beta-receptors in the peripheral nervous system: an analysis of sciatic nerve and dorsal root ganglia. Dev Biol 155:459-476.

Ellis LC, Youson JH (1990) Pronephric regression during larval life in the sea lamprey, Petromyzon marinus L. A histochemical and ultrastructural study. Anat Embryol 182:41-52.

Fawcett JW, Keynes RJ (1990) Peripheral nerve regeneration. Annu Rev Neurosci 13:43-60.

Feldman EL, Sullivan KA, Kim B, Russell JW (1997) Insulin-like growth factors regulate neuronal differentiation and survival. Neurobiol Dis 4:201-214.

Fernandez-Valle C, Wood PM, Bunge MB (1998) Localization of focal adhesion kinase in differentiating Schwann cells/neuron cultures. Microsc Res Tech 41:416-430.

Fiddes RJ, Janes PW, Sivertsen SP, Sutherland RL, Musgrove EA, Daly RJ (1998) Inhibition of the MAP kinase cascade blocks heregulininduced cell cycle progression in T-47D human breast cancer cells. Oncogene 16:2803-2813.

Funakoshi H, Frisén J, Barbany G, Timmusk T, Zachrisson O, Verge VMK, Persson H (1993) Differential expression of mRNAs for neurotrophins and their receptors after axotomy of the sciatic nerve. J Cell Biol 123:455-465.

Gaese F, Kolbeck R, Barde Y-A (1994) Sensory ganglia require neurotrophin-3 early in development. Development 120:1613-1619.

Gavrieli Y, Sherman Y, Ben-Sasson SA (1992) Identification of programmed cell death in situ via specific labeling of nuclear DNA fragmentation. J Cell Biol 119:493-501.

Glazner GW, Morrison AE, Ishii DN (1994) Elevated insulin-like growth factor (IGF) gene expression in sciatic nerves during IGFsupported nerve regeneration. Brain Res Mol Brain Res 25:265-272.

Grinspan JB, Marchionni MA, Reeves M, Coulaloglou M, Scherer SS (1996) Axonal interactions regulate Schwann cell apoptosis in developing peripheral nerve: neuregulin receptors and the role of neuregulins. J Neurosci 16:6107-6118.

Hall SM (1986) Regeneration in cellular and acellular autografts in the peripheral nervous system. Neuropathol Appl Neurobiol 12:27-46.

Hammarberg H, Risling M, Hokfelt T, Cullheim S, Piehl F (1998) Expression of insulin-like growth factors and corresponding binding pro- 
teins (IGFBP 1-6) in rat spinal cord and peripheral nerve after axonal injuries. J Comp Neurol 400:57-72.

Hardy M, Reddy UR, Pleasure D (1992) Platelet-derived growth factor and regulation of Schwann cell proliferation in vivo. J Neurosci Res 31:254-262.

Hart IK, Richardson WD, Heldin C-H, Westermark B, Raff MC (1989) PDGF receptors on cells of the oligodendrocyte-type-2 astrocyte (O2A) cell lineage. Development 105:595-603.

Hart IK, Richardson WD, Raff MC (1992) PDGF increases the expression of fos and jun in newly formed oligodendrocytes that have become resistant to the mitogenic effect of PDGF. Glia 6:310-313.

Jessen KR, Mirsky R (1997) Embryonic Schwann cell development: the biology of Schwann cell precursors and early Schwann cells. J Anat 191:501-505.

Jessen KR, Morgan L, Stewart HJ, Mirsky R (1990) Three markers of adult non-myelin-forming Schwann cells, 217c(Ran-1), A5E3 and GFAP: development and regulation by neuron-Schwann cell interactions. Development 109:91-103.

Jessen KR, Brennan A, Morgan L, Mirsky R, Kent A, Hashimoto Y, Gavrilovic J (1994) The Schwann cell precursor and its fate: a study of cell death and differentiation during gliogenesis in rat embryonic nerves. Neuron 12:509-527.

Kim HA, DeClue JE, Ratner N (1997) cAMP-dependent protein kinase $\mathrm{A}$ is required for Schwann cell growth: interactions between the cAMP and neuregulin/tyrosine kinase pathways. J Neurosci Res 49:236-247.

Kingston AE, Bergsteinsdottir K, Jessen KR, Van der Meide PH, Colston MJ, Mirsky R (1989) Schwann cells co-cultured with stimulated T cells and antigen express major histocompatibility complex (MHC) class II determinants without interferon- $\gamma$ pretreatment: synergistic effects of interferon- $\gamma$ and tumor necrosis factor on MHC class II induction. Eur J Immunol 19:177-183.

Kurek JB, Austin L, Cheema SS, Bartlett PF, Murphy M (1996) Upregulation of leukaemia inhibitory factor and interleukin-6 in transected sciatic nerve and muscle following denervation. Neuromuscul Disord 6:105-114.

Lee M-J, Brennan A, Blanchard A, Zoidl G, Dong Z, Tabernero A, Zoidl C, Dent MAR, Jessen KR, Mirsky R (1997) $P_{0}$ is constitutively expressed in the rat neural crest and embryonic nerves and is negatively and positively regulated by axons to generate non-myelin-forming and myelin-forming Schwann cells, respectively. Mol Cell Neurosci $8: 336-350$.

Lewin GR, Barde YA (1996) Physiology of the neurotrophins. Annu Rev Neurosci 19:289-317.

Li H, Wigley C, Hall SM (1998) Chronically denervated rat Schwann cells respond to GGF in vitro. Glia 24:290-303.

Martini R (1994) Expression and functional roles of neural cell surface molecules and extracellular matrix components during development and regeneration of peripheral nerves. J Neurocytol 23:1-28.

Meyer D, Birchmeier C (1995) Multiple essential functions of neuregulin in development. Nature 378:386-390.

Mirsky R, Jessen KR (1998) The neurobiology of Schwann cells. Brain Pathol, in press.

Morgan L, Jessen KR, Mirsky R (1994) Negative regulation of the $\mathrm{P}_{0}$ gene in Schwann cells: suppression of $\mathrm{P}_{0}$ mRNA and protein induction in cultured Schwann cells by FGF2 and TGF $\beta 1$, TGF $\beta 2$ and TGF $\beta 3$. Development 120:1399-1409.

Muir D, Varon S, Manthorpe M (1990) Schwann cell proliferation in vitro is under negative autocrine control. J Cell Biol 111:2663-2671.

Nadim W, Anderson PN, Turmaine M (1990) The role of Schwann cells and basal lamina tubes in the regeneration of axons through long lengths of freeze-killed nerve grafts. Neuropathol Appl Neurobiol 16:411-421.

Offenhäuser N, Böhm-Matthaei R, Tsoulfas P, Parada L, Meyer M (1995) Developmental regulation of full-length trkC in the rat sciatic nerve. Eur J Neurosci 7:917-925.

Oppenheim RW, Prevette D, Yin QW, Collins F, MacDonald J (1991) Control of embryonic motoneuron survival in vivo by ciliary neurotrophic factor. Science 251:1616-1618.

Oudega M, Xu XM, Guenard V, Kleitman N, Bunge MB (1997) A combination of insulin-like growth factor-I and platelet-derived growth factor enhances myelination but diminishes axonal regeneration into Schwann cell grafts in the adult rat spinal cord. Glia 19:247-258.

Owens GC, Boyd CJ (1991) Expressing antisense $P_{0}$ RNA in Schwann cells perturbs myelination. Development 112:639-649.
Pang L, Sawada T, Decker SJ, Saltiel AR (1995) Inhibition of MAP kinase kinase blocks the differentiation of PC -12 cells induced by nerve growth factor. J Biol Chem 270:13585-13588.

Pu SF, Zhuang HX, Ishii DN (1995) Differential spatio-temporal expression of the insulin-like growth factor genes in regenerating sciatic nerve. Brain Res Mol Brain Res 34:18-28.

Raabe TD, Clive DR, Neuberger TJ, Wen D, DeVries GH (1996) Cultured neonatal Schwann cells contain and secrete neuregulins. J Neurosci Res 46:263-270.

Raff MC, Barres BA, Burne JF, Coles HS, Ishizaki Y, Jacobson MD (1993) Programmed cell death and the control of cell survival: lessons from the nervous system. Science 262:695-700.

Rappolee DA, Sturm KS, Behrendtsen O, Schultz GA, Pedersen RA, Werb Z (1992) Insulin-like growth factor II acts through an endogenous growth pathway regulated by imprinting in early mouse embryos. Genes Dev 6:939-952.

Reilly TM, Taylor DS, Herblin WF, Thoolen MJ, Chiu AT, Watson DW, Timmermans PB (1989) Monoclonal antibodies directed against basic fibroblast growth factor which inhibit its biological activity in vitro and in vivo. Biochem Biophys Res Commun 164:736-743.

Riethmacher D, Sonnenberg-Riethmacher E, Brinkmann V, Yamaai T, Lewin GR, Birchmeier C (1997) Severe neuropathies in mice with targeted mutations in the ErbB3 receptor. Nature 389:725-730.

Rosenbaum C, Karyala S, Marchionni MA, Kim HA, Krasnoselsky AL, Happel B, Isaacs I, Brackenbury R, Ratner N (1997) Schwann cells express NDF and SMDF/n-ARIA mRNAs, secrete neuregulin, and show constitutive activation of erbB3 receptors: evidence for a neuregulin autocrine loop. Exp Neurol 148:604-615.

Ruggiero FP, Gonzalez M, Chang Q, Cannon AL, Rich MM, Kraner S, Balice-Gordon RJ (1998) Chronic adenovirus-mediated expression of truncated trk receptors in skeletal muscle fibers in vivo. Soc Neurosci Abstr 28:319.13.

Sara VR, Hall K (1990) Insulin-like growth factors and their binding proteins. Physiol Rev 70:91-614.

Scherer SS, Salzer JL (1996) Axon-Schwann cell interactions during peripheral nerve degeneration and regeneration. In: Glial cell development, basic principles and clinical relevance (Jessen KR, Richardson WD, eds), pp 165-196. Oxford: Bios Scientific.

Schumacher M, Jung-Testas I, Robel P, Baulieu E-E (1993) Insulin-like growth factor I: a mitogen for rat Schwann cells in the presence of elevated levels of cyclic AMP. Glia 8:232-240.

Stewart HJS, Eccleston PA, Jessen KR, Mirsky R (1991) Interaction between cAMP elevation, identified growth factors, and serum components in regulating Schwann cell growth. J Neurosci Res 30:346-352.

Stewart HJS, Bradke F, Tabernero A, Morrell D, Jessen KR, Mirsky R (1996) Regulation of rat Schwann cell $\mathrm{P}_{0}$ expression and DNA synthesis by insulin-like growth factors in vitro. Eur J Neurosci 8:553-564.

Svenningsen AF, Kanje M (1996) Insulin and the insulin-like growth factors I and II are mitogenic to cultured rat sciatic nerve segments and stimulate $\left[{ }^{3} \mathrm{H}\right]$ thymidine incorporation through their respective receptors. Glia 18:68-72.

Syroid DE, Maycox PR, Burrola PG, Liu N, Wen D, Lee K-F, Lemke G, Kilpatrick TJ (1996) Cell death in the Schwann cell lineage and its regulation by neuregulin. Proc Natl Acad Sci USA 93:9229-9234.

Terenghi G, Calder JS, Birch R, Hall SM (1998) A morphological study of Schwann cells and axonal regeneration in chronically transected human peripheral nerves. J Hand Surg [Br] 23:583-587.

Trachtenberg JT, Thompson WJ (1996) Schwann cell apoptosis at developing neuromuscular junctions is regulated by glial growth factor. Nature 379:174-177.

Van Wyk JJ, Graves DC, Casella SJ, Jacobs S (1985) Evidence from monoclonal antibody studies that insulin stimulates deoxyribonucleic acid synthesis through the type I somatomedin receptor. J Clin Endocrinol Metab 61:639-643.

Verdi JM, Groves AK, Farinas I, Jones K, Marchionni MA, Reichardt LF, Anderson DJ (1996) A reciprocal cell-cell interaction mediated by NT-3 and neuregulins controls the early survival and development of sympathetic neuroblasts. Neuron 16:515-527.

Wei J, Shaw LM, Mercurio AM (1998) Regulation of mitogen-activated protein kinase activation by the cytoplasmic domain of the $\alpha_{6}$ integrin subunit. J Biol Chem 273:5903-5907.

Weinberg HJ, Spencer PS (1978) The fate of Schwann cells isolated from axonal contact. J Neurocytol 7:555-569.

Wyllie AH (1980) Glucocorticoid-induced thymocyte apoptosis is associated with endogenous endonuclease activity. Nature 284:555-556. 